\title{
ANADOLU BARIŞI BAĞLAMINDA SAMSUN BOMBARDIMANI
}

\section{SAMSUN BOMBARDMENT IN THE CONTEXT OF ANATOLIAN PEACE}

\author{
Mehtap BAŞARIR*
}

BAŞARIR, Mehtap, (2020), “Anadolu Barışı Bağlamında Samsun Bombardımanı”, Belgi Dergisi, C.2, S.20, Pamukkale Üniversites Atatürk İlkeleri ve İnkılâp Tarihi Araştırma ve Uygulama Merkezi Yayını, Yaz 2020/II, ss. 2365-2391.

Öz

Milli Mücadele'nin önemli bir dönüm noktası kabul edilen Sakarya Savaşı'nda elde edilen zafer; askeri, siyasi ve moral üstünlüğünün Türk tarafına geçmesini mümkün kılmışıı. Türk ordusu, Sakarya zaferiyle Yunan ilerleyişini Anadolu'da durdurmayı başarsa da tam manasıyla Anadolu topraklarından Yunan gücünü çıkaracak güce o günün şartlarında sahip bulunmadığı için askeri hazılılıklarını da devam ettirmiştir. Sakarya'da elde edilen zaferden, Büyük Taarruz Savaşı'nın başlamasına kadar geçen (13 Eylül 1921'den 26 Ağustos 1922) yaklaşık on bir aylık süre zarfında bir taraftan askeri eksikliklerini gideren Türk tarafı bir taraftan da diplomasiyi elden bırakmayarak, Anadolu'da bir barış yapılacağına yönelik söylemlere duyarsız kalmamıştır. Sakarya Savaşı'ndan yenik çıkan Yunan ordusunun geri çekilmesi, Anadolu meselesinin silahla bitirilemeyeceğini teyit edince Yunan ordusunun arkasındaki destekçisi İngilizler barış çabalarına 1922'nin ortasından önce hız vermiştir. Bu kapsamda hem Avrupa hem de Türk kamuoyunu belli bir süre meşgul eden İngilizler, 22 Mart 1922'de Itilaf Devletleri Dışişleri Bakanlarını Paris'te bir araya getirmiştir. Paris Konferansı'nda çıkan mütareke teklifini milli emeller açısından uygun değerlendirmeyen Ankara hükümeti, barış müzakerelerinin başlaması için öncelikli olarak Anadolu'nun tahliye edilmesini şart koşmuştur. Böylece Ankara hükümeti Mîsâk-ı Millî şartlarını taşımayan bir barışa razı olmadığını açık bir biçimde dünya kamuoyuna göstermiştir. Bununla birlikte İzmit'te bir konferans yapılmasını önererek müzakere kapılarını tam manasıyla kapatmayan Ankara hükümeti, her türlü ihtimale karşı askeri hazırlıklarını da sürdürmüştür. i̇mit'te bir konferans düzenlenmesi teklifi aslında, dünya kamuoyu nezdinde, Ankara hükümetinin barış karşıtı görünmediğini ispat etmiştir. Ankara hükümeti, Itilaf Devletlerinin barış teklifine verdiği bu hamle ile kendisini dünyaya barış karşıtı göstermeye çalışan İngiltere'nin planını bozmuştur. Bu kez farklı bir adım atan İngiltere, Ege'de Yunanlıların Müslümanlara yaptığı zulümleri görmezden gelerek; bölgede Müslümanların Hristiyanlara zulmettiğine yönelik iddialar öne sürmüş ve bu iddiaların incelenmesi için Anadolu'ya bir heyet göndermek istemiştir. Böyle bir tutum içerisine giren İngiltere, dünya kamuoyu önünde Türklerin sözde zulümlerini öne çıkarmak suretiyle Türkler lehine işleyen sürecin yönünü değiştirmeyi hedeflemiştir. Haziran 1922'ye gelindiğinde ise Paris Konferansı sonrası Türk tarafı ile karşılıklı notalardan bir sonuç çıkmayacağı anlaşılmış ve adeta fırtına öncesi sessizlik İngiltere'nin desteklediği Yunan donanmasının Samsun'da harekete geçmesiyle bozulmuştur. Böylece diplomasi yoluyla çözülmesi beklenen Anadolu barışına önemli bir darbe indiren Yunanlılar, Ankara hükümetine baskı oluşturmayı hedefleyerek siyasi amaçla harekete geçmiş ve yine Müslümanların Hristiyanlara zulmettikleri iddialarına geçerlilik kazandırmak istemiştir. Bu çalışma, Sakarya Savaşı'ndan sonra Müttefik devletlerin sık sık dile getirdiği Anadolu barışı (Şark Salâhı) söylemeleri gölgesinde, İngiltere'nin desteklediği Yunan filosunun Samsun'da gerçekleştirdiği bombardımana odaklanmaktadır. Çalışma, Sakarya'dan Büyük Taarruz Savaşı'na kadar geçen yaklaşık bir yıllık süre içerisinde özellikle de İngilizlerin Anadolu barışı söylemlerine vurgu yaptığı bir dönemde, eyleminden haberdar bulunduğu Yunan donanmasının Samsun şehrini bombardımanına göz yummasına ilişkin Türkiye'ye yönelik iki yönlü politika değişiminin tespitini

* Öğr. Gör., Dr., Harran Üniversitesi Şanlıurfa Sosyal Bilimler MYO, Urfa, basarirmehtap@hotmail.com, (https:// orcid.org/0000-0001-6317-7469) 
amaçlamaktadır. Bu amaç çerçevesinde araştırmanın verilerini Devlet Arşivleri'nden elde edilen belgeler, TBMM ve İngiliz Avam Kamarası Zabıtları'nda konuyla ilgili söylemler, doküman incelemesi yoluyla İstanbul ve Ankara basınında yer alan haberler ile bu haberlerle alakalı başyazarların değerlendirmeleri ve literatürdeki temel eserler oluşturmaktadır. Sonuçta anlaşılmaktadır ki sadece Türk basını değil İngiliz Avam Kamarası'nda da Samsun bombardımanı, Anadolu barışına ket vuracak bir eylem biçiminde zikredilmiş ve aynı zamanda Yunan filosunun arkasında güç konumunda yer alan İngiltere de çeşitli söylemlerle eleştirilmiştir. Çalışma, Milli Mücadele dönemine ait özel bir devri ele almasıyla ilgili yazında benzerlerinden ayrılmaktadır.

Anahtar Kelimeler: Milli Mücadele, Türkiye ve Yunanistan, Yunan Filosu, Türkiye Büyük Millet Meclisi (TBMM), ingiltere, Samsun.

\begin{abstract}
Victory in the Battle of Sakarya, which is considered an important turning point of the National Struggle; made it possible for military, political and moral superiority to pass to the Turkish side. Although the Turkish army succeeded in stopping the Greek advance in Anatolia with the victory of Sakarya, it continued its military preparations as it did not have the power to extract the Greek forces from the Anatolian lands under the conditions of that day. During the eleven-month period from the victory in Sakarya to the start of the Great Attack War (September 13, 1921 to August $26,1922)$, the Turkish side, on the one hand, has compensated for its military deficiencies and on the other hand has not left diplomacy and was not insensitive to the discourses about a peace in Anatolia. When the withdrawal of the Greek army, which was defeated by the Battle of Sakarya, confirmed that the Anatolian issue could not be completed with war, the British supporters behind the Greek army accelerated the peace efforts before mid-1922. In this context, the British, which occupied both European and Turkish public opinion for a certain period of time, brought together the Foreign Ministers of the Entente States in Paris on 22 March 1922. The Ankara government, which did not consider the proposal at the Paris Conference suitable for national ambitions, required the evacuation of Anatolia primarily for the start of peace negotiations. Thus, the government of Ankara has clearly shown to the world public that it is not willing to make peace that does not meet the conditions of "Mîsak-ı Milli (The national pact or oath)". In addition to this, by proposing a conference in İzmit, the Ankara government did not close the doors of the negotiation, but also continued its military preparations against all odds. The proposal to hold a conference in Izmit proved to the world public opinion that the Ankara government was not against the peace. With its response to the peace proposal of the Entente States, Ankara government has disrupted Britain's plan, which was trying to make Ankara look anti-peaceful to the world. Britain, taking a different step this time, ignoring the persecution of Greeks to Muslims in the Aegean; made allegations that Muslims in the region persecuted Christians and asked to send a delegation to Anatolia to examine these allegations. With such an attitude, Britain, by emphasizing the so-called persecution of Turks before the world public opinion; aimed to change the process which was in favor of the Turks against the Turks. By June 1922, after the Paris Conference, it was understood that there would be no result from mutual notes with the Turkish side, and this pre-storm silence was broken down when the Greek navy backed by Britain took action in Samsun. Thus, the Greeks, who had a serious blow to the Anatolian peace, which is expected to be resolved through diplomacy, aimed to put pressure on the Ankara government and acted politically and again wanted to validate the claims that Muslims persecuted Christians. This study focuses on the bombardment of the Greek fleet supported by Britain in Samsun, in the shadow of the Allied states frequently voicing Anatolian peace (Eastern Peace) after the Battle of Sakarya. The study aims to determine Britain's bi-directional shift in policy towards Turkey; during the approximately one year from Sakarya to the Great Attack War, in the context of the Greek navy in which Britain was aware of its action, regarding the bombardment of the city of Samsun, especially at a time when the British emphasized Anatolian peace discourses. For this purpose, the data of the research constitute the documents obtained from the State Archives, Turkish Grand National Assembly's (TBMM) official reports and documents, Parliamentary discourses from the British House of Commons, document scanning method and the news in the national press and the reviews of the relevant authors and the information obtained through the main works related to the subject in the literature. As a result, it is understood that the Samsun Bombardment is mentioned in the form of an action that will hinder the peace of Anatolia; not only in the Turkish press, but also in the British House of Commons. At the same time, this action has been criticized in various discourses in England, which is the force behind the Greek fleet. The study
\end{abstract}


contains an originality that differs from its peers in the literature by examining a special period of the National Struggle period.

Keywords: National Struggle, Turkey and Greece, Greek Fleet, Grand National Assembly of Turkey (TBMM), Britain, Samsun.

\section{Giriş}

Birinci Dünya Savaşı'nın galipleri Müttefik Devletler ile arasındaki çarpışmaya son veren Osmanlı Devleti 30 Ekim 1918'de imzaladığı Mondros Ateşkes Antlaşması'nın ardından askeri işgal altına alınmıştır. Zaten mütareke imzalanırken Osmanlı Devleti'nin Arap ülkeleriyle diğer bazı bölgeleri Müttefik güçlerin fiili işgalindeydi. Ancak Mondros Mütarekesi'nin 1. Maddesi çerçevesinde, Boğazlar bölgesinin, Müttefik güçler tarafından askeri işgal altına alınacağı, 7. Maddesi çerçevesinde de "Müttefik güçlerin, güvenliklerini tehdit altında gördüklerinde, herhangi bir stratejik noktayı işgal edebilecekleri" öngörülmüştür. ${ }^{1}$ Böylece Müttefik güçler Osmanlı Devleti' nin çeşitli bölgelerini işgal etmeye başladılar. İstanbul, her üç ülkenin donanmaları tarafından kullanılan bir üs bölgesi haline geldi (İstanbul, İngiliz-Fransız ve İtalyan işgaline resmen 16 Mart 1920'de uğrayacaktır), İngilizler Musul'u, İtalyanlar Antalya ve Kuşadası'nı, Fransızlar da Adana, Urfa, Maraş, Antakya ve İskenderun'u mütarekeden sonra işgal edecektir. ilaveten İngilizler, hem silah toplamak hem de ulaşım sistemini denetlemek üzere İzmit, Eskişehir ve Samsun'u işgal ederken; Fransızlar Zonguldak; İtalyanlar da Konya'ya askeri birlik yerleştirmiştir. Yine 15 Mayıs 1919'da ABD, İngiltere ve Fransa, İzmir'i Yunanistan'a işgal ettirdiler. İşgallere karşı tepki gösteren Anadolu halkı, 1918 Kasım'ından itibaren yurdun işgale uğrayacağından korkulan yerlerinde, milli kuvvetler anlamına gelen "Kuvâ-yi Milliye" adıyla kurdukları direniş örgütleri etrafında silahlı kuvvetler kurarak bölgesel anlamda mücadele etmeye başladı. $^{2}$

Anadolu'da Müttefik güçlerin işgallerine karşı gelişen Milli Mücadele Hareketi, 9. Ordu Müfettişliği'ne atanan Mustafa Kemal Paşa'nın 19 Mayıs 1919'da Samsun'a çıkmasıyla başlamıştır. ${ }^{3}$ Dolayısıyla Samsun şehri, 9. Ordu Müfettişi Mustafa Kemal Paşa'nın, Müttefik Devletlerin Anadolu'da gerçekleştirdikleri işgallere karşı başlattığı Milli Mücadele'nin başlangıç noktasıdır. Bu özel durumunun yanı sıra Samsun, Anadolu'nun dışarı açılan kapısı konumuyla, Milli Mücadele'nin önemli bir merkezi haline de gelmiştir. Özellikle, Müttefik güçlerin, Anadolu'da kendilerine karşı oluşan Kuvây-ı Milliye hareketini abluka altında tutmak istemesi, Samsun şehrini coğrafi bakımdan daha da önemli kılmıştır. Buradan hareketle Karadeniz kıyısında yer alan Samsun, Anadolu'nun dış dünya ile bağlantı sağladığı aralıklardan biri olma konumunu sürdürmüştür. Samsun Limanı’nın yanı sıra Trabzon, Ereğli, İnebolu, Giresun ve Ordu gibi sahil şehirleri de hem Anadolu'nun dışa açılan kapısı, hem de Anadolu'ya giriş kapısı rolünü üstlenmiştir. Bu özelliğinin yanı sıra Samsun şehri, Müttefik güçlerin her biri hatta Amerika için ekonomik, askeri ve siyasi çıkarlar elde edebileceği üs konumundadır. Bu açıdan Karadeniz limanları, Kafkaslar,

1 Mehmet Gönlübol-Cem Sar, Atatürk ve Türkiye'nin Dış Politikası, Atatürk Araştırma Merkezi Yayınları, Ankara 2013, s.3.

2 Baskın Oran, "1919-1923: Kurtuluş Yılları: Dönemin Bilançosu ve Dönemin Yönetimi”, Türk Dış Politikası, C. I (1919-1980), Editör: Baskın Oran, İletişim Yayınları, İstanbul 2014, s. 112.

3 Yaşar Özüçetin, "Millî Mücadele İçerisinde "19 Mayıs 1919”, Gazi Üniversitesi Kırşehir Eğitim Fakültesi, Cilt 5 , Sayı 2, (2004), s. 68-70. 
Rusya, Anadolu, Balkanlar hatta Orta ve Yakın Doğu siyasetlerinin yönlendirilmesinde kayda değer bir öneme sahiptir. ${ }^{4}$

Amerika'nın Karadeniz'de, Samsun'a yerleşmesinde önemli rol oynayan etkenlerden birinin de Ermeni davası olduğunu söyleyebiliriz. Ne de olsa Ermeni davası ile en fazla meşgul bulunan Amerikan kamuoyudur. Bu açıdan Türkiye'den vazgeçemeyen Amerika, iç politikasının uygunsuzluğu sebebiyle Ankara hükümetini resmen tanımasa da dostane ilişkiler kurmaktan geri durmamıştır. ${ }^{5}$ Amerika, Anadolu'da varlık sürdüren Emeni ve Rum nüfusun korkunç baskı ve zülüm gördüğü propagandasından etkilenen bir ülke olduğundan, Anadolu içlerinden gelecek Ermeni ve Rumları Samsun'a çağırarak her türlü yardımı yapacağını bildirmiştir. ${ }^{6}$ Bu kapsamda Trabzon'daki Amerikan Yardım Kurulu, Ermeni ve Rumlara her türlü destek sağlamış ve talep edenlerin Trabzon'dan Batum'a ve başka yerlere gitme taleplerini karşılamıştır. Ayrıca ekonomik anlamda Amerikan işadamları ve Amerikan donanması 1919 yılından itibaren bölgedeki ekonomik kaynakları geliştirmek üzere Karadeniz'de seyreden gemilerin subaylarından bilgi toplamışlardır. Böylece Amerikan donanması bölgede hem taşıma işini yapmak hem de bilgi toplamak dışında Amerikan sermayesini korumak gibi birçok faaliyet yürütmüştür. Özellikle Samsun'daki Amerikan Tütüncülük Şirketi ${ }^{7}$, Samsun limanının Amerikan savaş gemilerinin üssü konumuna ulaştırılmasında önemli bir rol üstlenmiştir. ${ }^{8}$ Bu nedenle Samsun ve çevresi Amerikalılar için sürekli kontrol altında tutulması gereken bir bölge biçiminde zikredilmiştir. Böylece Samsun limanını sürekli üs haline getiren Amerika, en az bir savaş gemisini bu limanda hep hazır bulundurmuştur. Bir bakıma Amerikan ekonomisi açısından Batum limanından farklı olmayan Samsun limanı, Amerikan malları ve özellikle petrolü için de bir ekonomik üstü. Anadolu pazarını neredeyse tekeline alan Amerikalılar açısından, Türk limanları özellikle de Samsun limanı Amerikan mallarının örnekleriyle dolmuştur. Ayrıca Amerikan gemileri istihbarat amaçlı çalışarak, bilgi toplama işlevini de yürütmüştür ki bu tip istihbarat faaliyetlerinde Amerikan-İngiliz işbirliği güçlü bir biçimde sağlanmıştır. ${ }^{9}$

Müttefik güçlerden biri olan İngilizler açısından da Karadeniz sahilleri, dolayısıyla Samsun ve çevresi önem arz etmiştir. İngilizlerin Karadeniz sahilindeki abluka faaliyetleri, TBMM'nin açıldığı, Milli Mücadele'ye karşı isyanların yoğunlaştığı ve Sevr Antlaşması sürecinin devam ettiği bir dönemde daha da sıklaşmıştır. İngilizlerin amacı, bir taraftan isyancılara destek vermek, bir taraftan da milli hareket mensuplarına ve destekleyicilerine korku salmaktı. Ingiltere, Yunanistan'ın 1921 Mart'ının sonlarına doğru Türk kıyılarına resmen abluka uygulamaya başlamasıyla birlikte, bu kez Yunan donanmasıyla beraber Türk kıyılarına abluka uygulayacaktır. Bu durumun en önemli nedeni, Yunanistan'ın İnönü'de üst üste iki kere yenilmesiyle, İngiltere'nin yaşadığı endişedir. Böylece İngilizler, İstanbul'dan ve Rusya'dan milliyetçilere yapılan yardımları engellemek amacıyla, Yunanistan'ın Türk kıyılarına yönelik ilan ettiği ablukayı desteklemiştir. ${ }^{10} \mathrm{Ne}$ de olsa 1920 Ağustos' unda TBMM hükümeti ve Rusya arasında gerçekleştirilen Moskova Antlaşması'ndan sonra, Anadolu'ya

4 Rahmi Doğanay, “istiklal Harbinde Samsun'daki Amerikan Filosu”, Geçmişten Geleceğe Samsun, Samsun 2006, s. 163.

5 Rahmi Doğanay, Milli Mücadele'de Karadeniz (1919-1922), Atatürk Araştırma Merkezi Yayınları, Ankara 2016, s. 90.

6 Doğanay, a.g.m., s. 165-166.

7 Amerikan Tütün Şirketi ( American Tobacco Company), yetkilileri ticari faaliyet dışında başka bölgelerdeki Hristiyanlarla da ilgilenerek hem Amerikan hem de Avrupa kamuoyunu etkilemişlerdir. Doğanay, a.g.e., s. 165.

8 Doğanay, a.g.e., s. 201, 205. Ayrıntılı bilgi için bkz: Aynı eser, s.199-214.

9 Doğanay, a.g.m., s. 165-166.

10 Mehmet Okur, Milli Mücadele'de Karadeniz Bölgesi'ne Yönelik Ingiliz Faaliyetleri, Genelkurmay Askeri Tarih ve Stratejik Etüt Başkanlığı Yayınları, Ankara 2006, s. 172-173. 
yardım gelmeye başlamıştı. Gelen yardımlar ya doğrudan ya da Trabzon aracılığıyla İnebolu, Samsun ve Akçaşehir'e çıkarılıyor, oradan da Batı Cephesi'ne taşınıyordu. ${ }^{11}$

Yunanistan bütün çabalarına ve destekçisi İngiliz yardımlarına rağmen, Karadeniz limanlarını bombalama faaliyeti dışında, Batı Cephesi'ne silah taşınmasına engel olamamıştır. Bu duruma şahit olan İstanbul Müttefik Orduları Başkumandanı General Harrington, Savunma Bakanlığı'na rapor geçmiştir. Generale göre, Karadeniz kıyısına uygulanan ablukaya rağmen Rusya'dan Samsun'a, Trabzon'a ve diğer bazı şehirlere 1921 Temmuz ayının sonuna değin 800 ton askeri malzeme taşınmıştır. Yunan filosu, silah ve cephane taşıyan Türk gemilerini yakalamada başarısız olunca, Karadeniz sahili boyunca bazı limanları bombalamaktan geri durmamıştır. Bombardımana maruz kalan şehirler arasında Trabzon, Samsun ve İnebolu vardır. İngilizler, resmen katılmasa da bir taraftan Karadeniz'deki Yunan bombardımanını desteklemiş, bir taraftan da üslerini kullandırmıştır. ${ }^{12}$ İngiliz desteği ile Yunan donanmasının gerçekleştirdiği bu bombardımanlardan biri de 7 Haziran 1922'de gerçekleştirilen Samsun bombardımanıdır. Üstelik bu bombardıman, bir taraftan Batı Anadolu bölgesinde istediği başarıyı elde edemeyen Yunan ordusunun mevcut pozisyonunu korumak ve onları moral bakımından desteklemek; bir taraftan da Başkumandanlık Meydan Muharebesi'nin hemen öncesi yani Türk taarruzunun beklenildiği ve aynı zamanda Anadolu'da barış söylemlerinin ele alındığı bir döneme denk gelmektedir.

Neticede Anadolu'da Yunanlılara karşı kapsamlı askeri harekâtın başlamasından önce, diplomatik yolları denemek isteyen İngiltere ile bağlantılarını koparmak istemeyen TBMM hükümeti, Dışişleri Bakanı Yusuf Kemal Bey'i barış koşullarını yoklaması üzerine 1922 Şubat'ında hem Londra hem de Paris'e gönderdi. Lord Curzon'la Londra'da bir araya gelen Yusuf Kemal Bey, Mîsâk-ı Millî́yi İngiltere'ye kabul ettirememiştir. Ardından 1922 Mart'ında Paris'te Yusuf Kemal'le görüşen, İngiltere, Fransa ve İtalya temsilcileri, ateşkes de dâhil olmak üzere Sevr Antlaşması'nda değişikler öngören bazı önerilerde bulundularsa da bu öneriler TBMM hükümetince kabul edilmemiştir. Nitekim Ankara hükümeti ateşkesle aynı anda Anadolu'nun da boşaltılmasını talep etmiştir. ${ }^{13}$ Ancak İngiltere'nin, Ankara hükümetinin beklediği yaklaşımı göstermemesi ve Ankara'nın da İngiltere'nin tavrını, Anadolu'da geniş bir harekâta hazırlanmakta olan orduyu oyalamak ve gevşekliğe itmek biçiminde değerlendirmesi sonucu, bir anlaşmaya varılamamıştır. Neticede uzlaşma yolunun tıkalı bulunduğunun farkında olarak hareket eden Ankara hükümeti hazırlıklarını büyük ölçüde tamamlayan ordusuna, Büyük Taarruz'a başlama emrini verecektir. ${ }^{14}$ Fakat oraya gelinceye kadar TBMM hükümeti de barış kapısını açık tutarak, Müttefik güçlerin 11 Okur, a.g.e, s. 176; Doğanay, a.g.e., s. 118.

12 Okur, a.g.e., s. 177.

13 Karşılıklı notalarla geçen Mart-Nisan 1922 dönemini Mustafa Kemal şu şekilde kaydetmiştir: "Mütarekeyi esas itibariyle kabul ettik. Fakat esas şart olarak mütareke ile beraber tahliye işine süratle başlanmasını elzem saydık. Tahliyenin icra tarzı için de teklifimiz şu idi: Mütareke başlangıcından itibaren ilk on beş gün zarfında EskişehirKütahya-Afyonkarahisar genel hattının ve mütareke başlangıcından dört ay zarfında, İmir dahi dâhil olduğu halde, işgal edilmiş arazi tamamen tahliye edilecektir. Mütareke hakkındaki tekliflerimiz Müttefik devletlerce kabul edildiği takdirde, barış tekliflerini incelemek için üç hafta zarfında delegelerimizi kararlaştırılacak şehre göndermeye hazır olduğumuzu bildirdik. Bu notamıza 5 Nisan 1922'de olumsuz cevap verdiler. 22 Nisan'da buna cevap verdik. Bu cevabımızın nihayetinde, mütareke meselesinde mutabakat hâsıl olmasa bile, barış müzakerelerini ertelemenin uygun olmayacağını bildirdik. Izmit'te bir konferans toplanmasını teklif ettik. Bu haberleşme dahi neticesiz kaldı. Beykoz'da veya Venedik'te bir konferansın toplanması mükerreren söz konusu oldu. Fakat nihai zaferimizin tahakkuku anına kadar bunların hiçbiri gerçekleşmedi." Mustafa Kemal Atatürk, Nutuk, Atatürk Araştırma Merkezi Yayınları, Ankara 1997, s. 431-434. Mustafa Kemal Paşa'ya göre teklif edilen şartlar, istenilen barışın diplomatik yollarla kazanılamayacağına işarettir.

14 İlhan Uzgel, Ömer Kürkçüoğlu, "Batı Avrupa'yla İlişkiler: İngiltere'yle İlişkiler”, Türk Dış Politikası, C. I (19191980), Editör: Baskın Oran, İletişim Yayınları, İstanbul 2014, s. 146. 
barış teklifine karşın İzmit'te bir barış konferansı düzenlenmesini teklif etmiş̧ir. Bu durum, İngiliz Avam Kamarası Zabıtları'na da yansımıştır. İngiliz Parlamentosunun, 30 Mayıs 1922 tarihli oturumunda "Yakın Doğu" meselesi etrafında Anadolu barışı gündeme gelmiştir. Mr. Townshend, İngiltere'nin Anadolu'da Yunanlıları desteklemesini eleştirmiştir:

"Yunanistan'ı desteklememizin korkunç sonuçlarını hepimiz biliyoruz. Şu da doğrudur ki Ingiltere'nin desteği olmadan Yunanlılar işgal ettikleri bölgelerde beş dakika dahi kalamazlardı. Yunanlılar sahip oldukları muhteşem silahlara rağmen Sakarya Nehri'nde yenildiler. Sonra Kemal'e duralım diyorsunuz. Kemal böyle aptalca bir öneriyi kabul eder mi? Kendinizi onun yerine koyunuz. Biz artık burada durup başka bir yere gitmeyeceğiz mi diyeceksiniz? Kemal açısından meseleye baktığınızda, onun, nisan başında İzmit'te bir konferans teklif ettiğini görürsünüz. İzmit, Kemal'in Ankara ile irtibat kurabileceği bir yer. Ben eminim ki o konferanstan bir barış çıkacaktı. Birçok Türk'le konuştuğum için eminim. Izmir'deki Yunan mezalimi ile ilgili hazırlanan araştırma raporunu başbakan rafa kaldırdı. Ancak ben o araştırmayı gördüm, neticede Yunanlılar aleyhine hazırlanmıştı. Başbakan Izmit'e gidip Kemal'den taleplerini hafifletmesini isteyebilirdi. Hatta ben bunun için izmit'e gitmek istedim. Ben Kemal'i tanıyorum ${ }^{15}$ ve ona saygı duyuyorum. Kemal'e "Tanrı aşkına Kemal taleplerini yumuşat, barış yapmak zorundayız" der ve bu uğurda canı gönülden çalışırdım. Ancak Ingiliz Dışişleri Bakanlığı benimle aynı fikirde olmasa da ben kendi fikrimden vazgeçmiş değilim. Keşke başbakan İzmit'e gitmeye ikna edilse. Bence savaş haziran bitmeden yeniden başlayacak çünkü doğudan batıya doğru büyük bir Türk harekâtı var. Hükümetimiz izmit'e gitmeyerek, barış müzakerelerini baltaladı. Hükümeti eleştirmek istemiyorum, sadece kendi düşüncemin doğruluğundan eminim. Hâlâ vakit olmasından dolayı da hükümetin politikasını değiştirmesi için yalvarıyorum." ${ }^{16}$

Mr. Townshend'in Ingiliz hükümetinin, Anadolu politikasına ve Yunanlıların Anadolu'da yaptığı zulmü görmezden gelen tavırlarını yönelik eleştirileri, Türk basınında da söz konusudur. Bu bağlamda İngiltere'nin, İzmit konferansı teklifine olumlu cevap vermeyerek, güya Ege'de zülüm gören Hristiyanların durumunu araştırmak üzere Anadolu'ya bir heyet göndermeyi düşünmesi Türk kamuoyunda ve devlet adamları arasında nefretle

15 General Townshend: "Ben Kemal'i tanıyorum ve ona saygı duyuyorum" derken aslında doğrudan tanışıklığı kastetmemektedir. Nitekim Mustafa Kemal Paşa ile General Townshend 24 Temmuz 1922 tarihinde Konya'da görüşmüşlerdir.

Bir Türk dostu şeklinde tanımlanan General, Anadolu'daki gelişmeleri yakından takip ettiği için bir nevi Milli Mücadele lideri Mustafa Kemal'in yapacaklarını kestirebilme kabiliyetiyle yukarıdaki sözleri sarf etmiştir. Şöyle ki; Birinci Dünya Savaşı'nda Irak Cephesi'nde Osmanlı ordularıyla savaşan İngiliz kuvvetleri komutanı olan General Sir Charles Townshend Kût'ül-Amâre Muharebesi'nde başarısız olmasının ardından kuvvetleriyle birlikte 26 Nisan 1916'da Türk kuvvetlerine teslim olmuştur. Böylece esaret hayatını Birinci Dünya Savaşı'nın sonuna kadar İstanbul'daki önce Heybeliada'da ardından Büyükada'da geçiren Townshend, esir değil misafir muamelesi görmüştür. General Townshend İstanbul'da kaldığı sürede, Türkler ile yakın temasta bulunmuş ve bu durum neticesinde bir Türk dostu olarak tanımlanmıştır. Mondros Mütarekesi görüşmelerinde arabulucu olan General, mütareke sonrasında ülkesine dönmüş ve Türk destekçiliğini ve dostluğunu sürdürmüş, İngilizlerin Anadolu'da bir sulha ulaşması için Mustafa Kemal'e yaklaşmasını ve onunla doğrudan görüşmesini önermiştir. Mustafa Kemal'le henüz birebir tanışmamış olsa da İngiltere'nin Yakın Şark siyasetini eleştirerek, Türklerle Yunanlılar arasındaki mücadelenin durdurulmasına taraftar tutum sergilemiştir. (Ayrıntılı bilgi için bkz: Osman Akandere, Cemal Güven, "İngiliz Generali Townshend'in Anadolu Seyahati ve Mustafa Kemal Paşa ile Konya'da Yaptığı Görüşme", sü Atatürk ilkeleri ve Inkılap Tarihi Araştırma ve Uygulama Merkezi Ata Dergisi, S. 9, Konya 2002, s. 4-12, 21.

16 NEAR EAST, HC Deb 30 May 1922 vol 154 cc2027-54. (7 Haziran 1922'de gerçekleşen Samsun Bombardımanına ilişkin Avam Kamarası görüşmelerine yansıyan konuşma ve yorumlar da çalışmada değerlendirilmiştir. Böylece bombardımana yönelik yorumlar, milletvekillerinin hükümete yönelttikleri sorular ve onlara verilen cevaplar çalışmada kullanılarak İngiliz Avam Kamarası'nın olaya yönelik bakış açısı; Samsun Bombardment (Samsun Bombardımanı), Near East (Yakın Doğu), Greece and Turkey (Yunanistan ve Türkiye) ve Bosphorus (Boğazlar) başlıkları altındaki tutanaklardan ortaya konulmaya çalışımıştır.) 
karşılanmıştır. İngilizlerin attığı farklı adım şüphesiz Avrupa kamuoyunda, Türklerin lehine oluşan havayı dağıtmaktı. ${ }^{17}$

İngilizlerin barışı engelleyen adımları, iki savaş arası dönemde devam eden ateşkes görüşmelerinden bir netice çıkarmayacaktır. Nitekim Yunanlıları destekleyerek Türk tarafında baskı oluşturmak isteyen İngilizlerin gerçekleştirdiği eylemlerden biri de 7 Haziran 1922'de Yunan donanmasını harekete geçirerek, Samsun bombardımanında oynadığı roldür. Biz de çalışmamızda Büyük Taarruz Savaşı'ndan hemen önce İngiltere'nin desteğiyle Yunan donanmasının gerçekleştirdiği Samsun bombardımanı ele alacağız.

\section{Samsun Bombardımanı (7 Haziran 1922)}

1921 yılı başlarından itibaren Karadeniz'de Türklere karşı abluka uygulayan yine zaman zaman limanları ve şehirleri bombalayan Yunanistan 1922 Haziran'ında yeniden harekete geçmiştir ${ }^{18}$ Böylece on savaş gemisinden oluşan Yunan filosu İstanbul Boğazı'ndan geçerek Karadeniz'e çıkmıştır. Denizdeki bu hareketlilik, gözetleme istasyonlarından, Şile'den başlayarak bütün Karadeniz kıyılarında bulunan liman reisliklerine telgrafla bildirildiği için Ankara Bahriye Dairesi hareketlilikten haberdardır. Yunan filosu başta Amiral gemisi 10 bin tonluk Averoff ve 15 bin tonluk Kılkış zırhlıları olmak üzere, panter sınıfı iki muhrip, iki muavin kruvazör ve dört mayın arama-tarama gemisinden oluşmaktadır. 7 Haziran sabahı Samsun önlerine gelen filo komutanının öncelikle limanı mayından temizlemek üzere işe koyulması üzerine, Samsun'daki bahriyeliler şehrin bombardıman edileceğini anlamışlardır. Bu askeri çıkarmanın belki de karaya asker çıkarma amacı güttüğünü varsayan TBMM hükümeti, karada her türlü tertibatı alması için 15. Tümen Komutanı Albay Cemil Cahit Bey'i bilgilendirmiş, C. Cahit Bey de birlik komutanlarını gelişmelerden haberdar etmiştir. ${ }^{19}$

Yunanistan'ın Samsun'a yönelik harekâtındaki maksadı, İç Anadolu ve özellikle Batı Cephesi'ne taşınmak için önemli nakliyatın indirildiği Samsun limanını işlemez duruma getirmektir. Bu bağlamda, Enosis vapurunun Türk denizcilerce ele geçirilmesine karşılık, kıyı bölgesinde yaşayan Pontus çetelerine moral vermek ve Müslüman halkı heyecana sevk etmekte İngilizlerin güttüğü amaçlar arasındadır. ${ }^{20}$

Yunan donanmasının Samsun'a girdiği sırada, şehirde Ankara'ya sevk edilmek üzere çok miktarda cephane mevcuttur. Depolar ise mayın silahlarıyla doluydu. Üstelik iskele üzerinde şehre yeni gelmiş cephane sandıkları bulunmasına rağmen, Samsun, müstahkem veya silahlı bir şehir değildi. Dolayısıyla düşmanın burayı bombardıman etmesi uluslararası hukuka aykırıydı, ancak niyetleri açık bulunduğundan, iskele üzerindeki cephane hızı biçimde kaldırılarak, yangın söndürme tertipleri alındı. ${ }^{21}$

Saat 10:00 sularında Samsun Limanı'na ulaşan Yunan donanması kumandanı, bir Amerikan torpidosu kumandanı ${ }^{22}$ vasıtasıyla Samsun Valisine öncelikle bir ültimatom vermiştir. Yunan donanması verdiği ültimatomda, Yunan komisyonunun göstereceği

17 Hüsnü, "Ingilizlerin Son Oyunu”, Açıksöz, 24 Mayıs 1922, No: 493, s. 1.

18 Doğanay, a.g.e., s. 109-110.

19 Emrullah Nutku, "Samsun Bombardımanı ve Kahramanlık Yarışı", Yakın Tarihimiz, C. 4, S. 41, İstanbul 1962,

s. 60.

20 Doğanay, a.g.e., s. 109-110.

21 Nutku, a.g.m., s. 60.

22 Bu Amerikan zırhlısı 248 No'lu Sands zırhlısıdır. Sands zırhlısının kaptanı ise R. H. Ghormley'dir. Kaptan Ghormley, Naxos'a çıkıp Yunan subayı ile görüşür. Ghormley, Yunan subayından aldığı, Yunan Kraliyet Filosu Kaptanı Vriacaos'un mektubunu, kıyıya çıkarak, telgrafhanede buluştuğu, Samsun Valisi Faik Bey ile Fırka Kumandanı C. Cahit Bey'e verir; Doğanay, a.g.m., s. 168. 
şekilde şehirdeki bütün topların ve savaş malzemelerinin bir saat içerisinde imha edilmesini istemiştir. ${ }^{23}$ Ültimatomun devamında belirtilen taleplerin kabul edilmediği takdirde Lahey Konferansı kararlarına dayanarak şehrin derhâl bombardıman edileceği bildirilmiştir. ${ }^{24}$ Yunan amiralinin, Samsun valisine verdiği ültimatomun suretine ulaşan Hâkimiyet-i Milliye gazetesi, amiralin verdiği ültimatomdaki "maskaralıkları" kamuoyuna sunmuştur:

"Yunan amirali ültimatomda utanmadan Yunan donanmasının, Hristiyanlara karşı işlenen mezalimin devamını kabul etmediği için haklı olarak harekete geçtiğini söylemektedir. ${ }^{25}$ Böylece bombardımandan maksat, halkı sadece Hristiyanlara karşı tahrik etmektir. İste yukardaki cümleler, bu emeli hiç de saklamıyor. Gariptir ki bizi zalimlikle suçlayan Yunan kumandanının attığı mermilerin yarısı güya himayesini talep ettiği Hristiyanların evlerine, kiliselerine ve yetimhanelerine isabet etmiştir. Bu gülünç tedbirler ve gürültüler karşısında memleket içerisinde bulunan Hristiyanlar çoktan hükümlerini vermişlerdir. Amiralin verdiği ültimatom gerçekten gülünecek küstahlıklar ve adiliklerle doludur. Ültimatomdaki talepler Yunan ruhuna uygun olduğundan hayretle karşılamıyoruz. Yunanlıların bu küstah ültimatomu şöyledir:

"Yunan donanması başkumandanı amiralin emriyle, sizi, bizim tarafımızdan belirlenen Yunan subaylarından oluşan komisyonun önünde, Samsun'da mevcut bulunan bütün silahlarınızı, mühimmatınızı ve diğer savaş malzemelerini tahrip etmeye çağırıyoruz. Tahrip işlemi bugün 12.15'ten itibaren bir saat süre içerisinde 13.15'ten (İstanbul saatiyle) önce başlamalıdır. Tahribe zamanında başlamak üzere bütün hazırlıklarınızı yapmalısınız. Eğer bu talebi yerine getirmezseniz, belirtilen saatten sonra ikinci Lahey Konferansı antlaşmasının onuncu maddesini ${ }^{26}$ uygulayacağız ve bu konuda bir kopyayı size gönderiyorum. Buna göre, tatbik edilecek maddeye göre, tarafsız devletlerin temsilcileri ile konsolosluklarla temasa geçerek, belirtilen saatten önce tebaalarını Samsun'dan çıkarmalarını sağlayın. Aynı şekilde şehirdeki sivil halkı da çıkarınız. Bu talepleri yerine getirmez veya geciktirir ya da direnirseniz, bombardımanın sebep olacağı tahribattan dolayı biz hiçbir zaman mesuliyet kabul etmeyeceğiz."'n27

Türk tarafının cevabı hazır oluncaya kadar, şehirdeki Amerikan vatandaşlarının çıkarılmasını isteyen Ghormley, İstanbul'daki İtalyan Yüksek Komiseri'nden yardım istemiştir. Ancak Ankara hükümeti, açık şehir konumundaki Samsun'da Yunanlıların

23 Hâkimiyet-i Milliye, 8 Haziran 1922, No: 526, s. 1.; Yeni Gün, 8 Haziran 1922, No: 511-888, s. 1.

24 Hâkimiyet-i Milliye, 8 Haziran 1922,No, 526; TBMM Zabıt Ceridesi, 1. Dönem, 20. Cilt, 50. Birleşim, 08.06.1922, s. 248.

25 Samsun'daki bombardımanı haber yapan The Times gazetesinin 13 Haziran 1922 tarihli baskısında, Güney Batı Anadolu'da yer alan Fethiye'den yeni dönen İtalyan Kızıl Haç cerrahı Dall'Oglio'nun, Milliyetçi Türklerin Fethiye ve çevresindeki Yunan nüfusu Malatya ve Konya'ya sürgün ettiğine ve çok sayıda kimsenin uzun yürüyüş sırasında hayatını kaybettiğine yönelik iddiaları yer almaktadır. The Times, 13. 06. 1922, s. 7. The Times gazetesinin bombardıman haberinin hemen arkasına alakasız biçimde Milliyetçi Türklerin Hristiyan nüfusa yönelik mezalim haberini iliştirmesi pek tesadüf görülmemektedir. Böylece İngiliz basınının, Yunan donanmasının Hristiyanlara karşı işlenen sözde mezalimi kabul etmediği için Samsun bombardımanı eylemini gerçekleştirmesine haklılık payı vererek kamuoyunu yönlendirdiğini belirtebiliriz.

268 Haziran 1922 tarihli TBMM oturumunda İçişleri Bakanı Ali Fethi Bey Samsun bombardımanı hakkında gelişmeleri aktarırken, i̇kinci Lahey Konferansı'nın onuncu maddesini de açıklamıştır. Buna göre: Yasaklara; askeri tahkimat, askeriyeye ve bahriyeye ait silah depoları, savaş malzemeleri, fabrikalar ve icabında ordu ya da donanmanın istifadesine yarayan tezgâhlar dâhil değildir. Verilen süre içerisinde memurin tahribe başlamazsa Donanma Kumandanı makul bir süre vererek tebligattan sonra bunları topla tahrip edebilir. Bundan dolayı bombardımanın sebep olacağı zayiattan dolayı hiçbir sorumluluk söz konusu değildir; TBMM Zabıt Ceridesi, 1. Dönem, 20. Cilt, 50. Birleşim, 08.06.1922, s. 234.

27 Hâkimiyet-i Milliye, 9 Haziran 1922, No: 527, s. 1.; TBMM Zabıt Ceridesi, 1. Dönem, 20. Cilt, 50. Birleşim, 08.06 .1922 , s. $233-234$ 
yaptığı şeyin bütünüyle haksızlık mahiyeti içerdiğini söyleyerek, şehirdeki diğer yabancılar gibi Amerikalıların da korunacağını bildirmiştir. Ankara hükümeti açıkça söylemese de ecnebilerin Samsun'da bulunmasının bombardımanı engelleyeceğini düşünerek hareket etmiş ve bu doğrultuda Amerikalıların korunacağını öne çıkarmıştır. ${ }^{28}$

Diğer taraftan, Samsun Valisi Faik Bey Yunan donanma komutanının ültimatomuna verdiği cevap şu şekildedir:

"Amerikan muhribi aracılığıyla göndermiş olduğunuz mektubunuzu almış bulunuyoruz. Bu mektuba yanıt olarak Samsun kentinin açık bir kent olduğunu ve bombardıman edilmesinin yasalara aykırı olacağını belirtiriz. Ayrıca şu noktalara değinmek isteriz: Önerdiğiniz koşullar, kabul edilecek gibi değildir, bu nedenle reddediyoruz. Konsoloslar, yabancılar ve başka uluslardan ve dinlerden kimseler kalacaktır. Kentiterk etmeyeceklerdir. Böyle bir durumun sorumluluğu sizin üzerinizde kalacaktır. ${ }^{29}$

Fark edileceği üzere Vali Faik Bey, Samsun'un müstahkem bir yer olmadığı için hukuken bombardıman edilemeyeceğini belirtmiştir. Ayrıca konsoloslar, yabancılar ve azınlıklar dâhil birçok vatandaşın şehirde dağınık bir biçimde yaşadığını belirtmiştir. Illaveten Faik Bey, bombardıman sırasında akacak kanın tüm sorumluluğunun Yunanlılara ait olacağını da söylemekten geri durmamıştır. ${ }^{30}$

Neticede basında "hain düşman" biçiminde tanımlanan Yunanlılar verdikleri sürenin bitmesini dahi beklemeden şehrin her tarafını rastgele bombalamıştır. ${ }^{31}$ Yunanlıların yaptığı bu bombardıman basında yakışıksız bir eylem ve namussuzca bir hareket biçiminde tanımlanırken aslında can çekişen Yunanlıların amacının askeri değil siyasi olduğuna dair vurgu söz konusudur. Böylece Türk basınına göre, Yunanlıların birçok masumun kanının akmasına neden olan bu saldırısı; Türkleri Hristiyan Rumlara ve Samsun'daki Amerikan vatandaşlarına karşı tahrik etmektir. Böylece Yunanlılar, Avrupa'da, Türklerin Hristiyanlara zülüm yaptıklarına dair kopartılan gürültüleri teyit ettirmek niyetindedir. ${ }^{32}$ Ayrıca memleket dâhilinde bulunan Rumları, Türklerin aleyhine teşvik etmek, Türkler arasına da heyecan salmak isteyen Yunanlılar, bu heyecandan doğacak karışıklık esnasında Rumlara karşılık verecek Türkleri, sonra da Samsun'da yaşayan Amerikalılar aleyhinde kışkırtmak suretiyle asıl kendi yaptıkları mezalimin gürültülerini uzaklaştırmak istemişlerdir. Fakat Türkiye hükümeti, bir taraftan mevcudiyet ve istiklali için mücadele ederken, diğer taraftan aldığı tedbirler sayesinde Samsun ve memleket dâhilinde bir hadisenin yaşanmasına izin vermemiştir. Böylece hem İslam hem de Hristiyan herkes kendi işi ve gücüyle alakadar olduğundan, Yunanlılar elde etmek istediği siyasi emeli gerçekleştirememiştir. Ancak kamuoyunu; propaganda, telkin ve kışkırtmalar ile Türkiye'nin ve Türklerin aleyhine çevirmek isteyen Yunanlılar ile birlikte hareket ettiği kabul edilen İngiliz ricalinin bir ekalliyetler meselesi yaratmak istemesi Türk basını vasıtasıyla sert dille eleştirilmiştir. ${ }^{33}$ Böylece basın, Samsun'un bombardımanı neticesinde adeta ağız birliği yaparak, yaşanılan gelişmelerin ne devletler hukuku ne de insanlık esasları ile açıklanabileceğini öne çıkarmıştır. Bu bağlamda bombardımanın, İngiltere'nin son günlerde ortaya attığı Anadolu'da Hristiyan azınlığa zülüm yapıldığı söylentilerini desteklemek için yapıldığı basın kanalıyla ortaya konulmuştur.

28 Doğanay, a.g.m., s. 170.

29 Tuğba Eray Biber, Karadeniz Rumları ve Yunanistan (1914-1923), Yeditepe Yayınevi, İstanbul 2016, s. 181.

30 Yeni Gün, 8 Haziran 1922, No: 511-888, s. 1.

31 Hâkimiyet-i Milliye, 8 Haziran 1922, No: 526, s. 1.

32 Hâkimiyet-i Milliye, 8 Haziran 1922, No: 526, s. 1.

33 Hâkimiyet-i Milliye, 8 Haziran 1922, No: 526, s. 1. 
Ayrıca basın, Türkleri zulüm yapan bir toplum biçiminde gösterilmesinin hangi vicdana sığabileceğini de sorgulamaktadır. Nitekim bir taraftan tahkikat lüzumundan bahseden İngiliz Parlamentosu'nun diğer taraftan bir plan gereğince Samsun'u Yunan donanmasına bombardıman ettirmesi basının gözünden kaçmamıştır. Buradan hareketle Avrupa kamuoyuna ve vicdan sahiplerine seslenen basın, zulmün aslında hangi taraftan geldiği noktasında hüküm vermelerini dahi istemektedir. ${ }^{34}$ Hâkimiyet-i Milliye gazetesinde çıkan isimsiz başmakalede de İngiliz hükümeti, Samsun bombardımanından dolayı eleştirilecektir. Makalede Yunanistan'ı himaye ve teşvik eden İngiliz devlet adamlarının "mezalim efsanesi"ne takılarak milletleri Türkiye aleyhine tahrik ettirmek amacı güttüğü belirtilmektedir. Ayrıca çözülme içerisinde bulunan Yunanistan'ın vaziyetini gizlemek amacıyla son kuvvetiyle Samsun bombardımanını planlarken İngiliz desteğini aldığını belirten yazı şu şekildedir:

"Şarkta sulhtan bahseden Yunan matbuatı ve devlet adamları arkalarında ingiliz desteği ile hareket ederek Samsun'u bombardıman etmişlerdir. Ingiltere ve Yunanistan'ın maksadı, sözü edilen barış şartlarını Türkiye'ye kabul ettirmektir. Fakat TBMM hükümeti ve Türk kamuoyu bütün tahrikleri ve emelleri sağduyu ile karşılamıştır. Neticede Türk kendi hakkından emindir! Çünkü Türk, harp için harp değil, sadece Misâk-ı Millî adıyla tüm dünyada bilinen hukuk-ı tabiiyesini meşru kılmak için harp etmekte bulunduğunu ve dolayısıyla meşru haklarına saygı duyan bir sulha da hazır olduğunu açık bir dille belirtmiştir. Daima sulhtan sözde bahseden ve insanlığın ıstırabı karşısında harekete geçen Ingiliz hükümeti, Türklerin bu açık sözleri karşısında mat olmuştur. Neticede biz sulhtan çekinmediğimizi söylememizin yanı sıra düşmanlarımızı müzakereye davet ederek, bütün milletler için tanınmış olan hukuktan başka bir şey talep etmedik. Bu kadar açık vaziyet karşısında ingiliz riyakârlığı şaşırdı: Teklifimizi ret etmedi, çünkü âlem önünde pek ayıp olacaktı. Gerçekte ingiltere'nin istediği şarkta sulh ve selametin devam etmesi değil, karışıklık ve kargaşalığın devam etmesidir. Bu noktada ingiliz hükümeti bir taraftan sulhtan bahsederken bir taraftan da Yunan donanmasının Samsun'a hücum etmesine onay vererek âlemi Türklere karşı tahrik etmek istemiştir. Yani Ingiliz hükümeti, Anadolu'da Müslümanlar ve Hristiyanlar arasında karışılık çıkartarak, Türkler hakkında yayılan mezalim efsanelerini yaymak ümidi ile hareket etmiştir. Yunanlılar ise aynı hadiseden yararlanarak Amerika ile diğer devletlerin müdahalelerini kazanmak hayaline kapılmışlardır. Fakat her zaman olduğu gibi Türk sabrı, temkini ve sağduyusu bütün şeytanlıkları sonuçsuz bırakmıştır. Ancak ortada dökülen bir kan olduğu gibi, yanan bir şehir ve tahrip olan halkın evleri vardır. Bu nedenle Loyd George ve arkadaşları Şark'ta daima kan akmasını istediği için Samsun şehri viran olmuştur. "Tan gazetesi" bu manzara önünde adeta isyan etmektedir: "Neden Şark'ta Loyd George hükümeti barış tesis temek yerine Türkler tarafından da vaki olan müzakere davetine cevap vermiyor ve müzakere yerine dünyayı velveleye vererek tahkikat yapılmasını talep ediyor." Gazeteye göre bu soruların tek cevabı, Ingiliz hükümetinin bağımsız ve hür bir Türkiye arzu etmemesidir. Bu nedenle Tan gazetesi için, Samsun'da dökülen kanların ve tahrip olan evlerin tek sorumlusu Loyd George ve arkadaşlarıdır. Tan yazının devamında şöyle demektedir: "Yunanlılar, Loyd George hükümetinin elinde yalnız kör ve alçak bir alettir. Onların emri ve arzuları doğrultusunda hareket ediyorlar. Eğer Loyd George, Yunanlıları teşvik ve himaye etmeseydi, Yunanlılar hiçbir zaman Samsun bombardımanı gibi eylemlere kalkışamazdı. Bu nedenle bombardımandan Yunanistan değil Ingiliz hükümeti sorumludur ki bu gerçeği bütün dünya ve islam âlemi bilmelidir."'135

34 Hâkimiyet-i Milliye, 8 Haziran 1922, No: 526, s. 1.

35 “Mesul Kimdir?", Hâkimiyet-i Milliye, 9 Haziran 1922, No: 527, s. 1. 
Fark edileceği üzere basın, açık bir biçimde, Samsun bombardımanın arkasındaki güç konumunda nitelendirdiği İngiltere'yi sert dille eleştirmiştir. Neticede de bombardımanla birlikte Türk hükümetinin aldığı tedbirler ve Türk halkının sağduyusu sayesinde Hristiyan vatandaşlara karşı herhangi bir tepki ortaya çıkmamış aksine bombardıman sonrasında hem Müslüman hem de Hristiyan vatandaşlar kendi işleri ile meşgul olmaya başlamıştır. ${ }^{36}$ Bu durumda İngilizlerin dünya kamuoyunu Türkler aleyhine çevirme planı başarılı olmamıştır. ${ }^{37}$

Yine basında, Samsun bombardımanının Yunan vahşetinin alçaklık derecesini bir kat daha büyüttüğünden bahsedilerek, adi bir plan kapsamında Yunanlıların tam ruhsat ile ve hızlı biçimde rastgele bombardımana tabi tuttukları Samsun'a dört yüzden fazla top mermisi savurdukları ve neticede her bir top mermisinin müdafaasız halktan birilerinin evine, malına ve canına zarar verdiği öne çıkmaktadır. Illaveten bazı top mermileri de Türklerin zulüm yaptığı iddia edilen Hristiyanların evlerine, kiliselerine ve yetimhanelerine isabet etmiştir. ${ }^{38}$ Böylece uluslararası hukuka aykırı yapılan bu saldırıda atılan mermiler hükümet konağına, yolcu iskelesine, gümrük depolarına, Ermeni Kilisesi'ne ve birçok Müslüman ve Hristiyan ahalinin evlerine isabet ettiği gibi, önemli sayıda can ve mal kaybına da neden olmuştur. ${ }^{39}$ Aynı zamanda bombardıman neticesinde belediyeye ait gazhanede 41.770 teneke gaz, 68.368 kilo benzin ve 900 kilo ispirto heba olmuş; sivil ölümleri kapsamında ise dört askeri şehit olmuş, üç asker ise yaralanmıştır. ${ }^{40}$

Yaşanılan Samsun bombardımanı üzerine Ankara durumu protesto edecektir. Samsun bombardımanını, TBMM hükümetinin Dışişleri Bakanı Yusuf Kemal Bey 8 Haziran tarihli notasıyla, Yunan filosunun korsanlıkları ve İstanbul'u aşan suçlarından dolayı Yunanistan'ı protesto etmiştir. Buradan hareketle Yusuf Bey'in aşağıda yer alan notası İstanbul'daki Müttefik ve bitaraf devletler temsilcilerine verilmiştir:

"TBMM hükümetinin Dışişleri Bakanı 8 Haziran tarihli notasıyla Samsun açık şehrinin 7 Haziran'da bir Yunan filosu tarafından bombardıman edilmesine karşı protestoda bulunmuş ve düşman tarafından takip edilen siyasi gayeler hakkında büyük güçlerin dikkatini çekmiştir. Geçen sene haziran başında, aynı şekilde açık bir şehir olan inebolu ${ }^{41}$ 'da gerçekleşen saldırının hedefi gibi Samsun taarruzunun hedeflediği gaye, Türk hükümetine karşı isyan hususunda sahil Rumlarını yüreklendirmekti. Yunan filosu bombardımanı gerçekleştirdikten sonra mühimmat ve kömürünü almak için istanbul'a geri dönmüş, daha sonra tekrar Karadeniz'e çıkarak Türk gemilerine taarruz etmiş, bir kaçını batırmış ve

36 Yeni Gün, 8 Haziran 1922, No: 511-888, s. 1.

37 “Samsun'un Bombardımanı", Açıksöz, 8 Haziran 1922, No: 502, s. 1.

38 Hâkimiyet-i Milliye, 9 Haziran 1922, No: 527, s. 1. Nutku makalesinde, Yunan filosunun 3 saat süren bombardıman esnasında 548 mermi harcadığını, Türk bataryasının bir mermisinin düşman kruvazörünün güvertesine isabet etmesinin ardından düşman filosunun ateş kesmeye ve uzaklaşmaya mecbur kaldığını belirtmektedir. Ayrıca şehirde maddi hasarın önemli miktarda bulunduğunu aktaran Nutku, dört erin şehit olduğunu, Ermeni yetimhanesinde üç çocuğun öldüğünü, benzin ve petrol sarnıçları ile tütün depolarının tahrip edildiğini, Amerikalılara ait tütün depoları ile Ruslara ait benzin ve petrol sarnıçlarının tahrip olurken, depoların yanında bulunan mayın depolarının hiç isabet almadığını ayrıca cephane depolarının da zarar görmediğini söylemektedir; Nutku, a.g.m., s. 60.

39 Hâkimiyet-i Milliye, 9 Haziran 1922, No: 527, s. 1.

40 Biber, a.g.e., 183.

41 Müttefik güçler 8 Haziran 1921'de üstelik Ramazan Bayramı́nın birinci gününde askeri mühimmat sevkiyatı yapıldığı gerekçesiyle İnebolu'ya yani masum insanların üzerine bomba yağdırmış fakat beklenenin aksine tıpkı Samsun bombardımanı gibi Türkler, Hristiyan halk aleyhinde bir faaliyette bulunmamıştır. Türk basınına göre, bu tarz bombardımanlardan İngilizlerin maksadı, Anadolu'da azınlıklar aleyhinde zulüm yapılıyor gürültüsü çıkartarak, Anadolu'ya inceleme heyeti gönderme amacını gerçekleştirmektir; Abdülahad Nuri, "Samsun'un Bombardımanı", Açıksöz, 10 Haziran 1922, No: 503, s. 1. 
İstanbul'a yeniden dönmüştür. Son alınan haberlere göre, Karadeniz'e giden Yunan muavin kruvazörü ile torpidosu hala Karadeniz'e girip çıkan Türk köylerini karıştırmakla meşguldür. Boğazın giriş civarında sağlanan müsaade noktasına varan bütün Türk yelkenlileri ve kayıkları batırılarak, mürettebat esir sıfatıyla Midye'ye götürülmekte ve orada pek sert bir muameleye tabi tutulmaktadır. Bu durum, Anadolu barışının sağlanmasına son derecede zararlıdır. Buradan hareketle Yunanistan'ın sahil Rumlarını uyandırarak, Türk hükümetine karşı harekete geçirmek maksadını, tamamen barış taraftarı bulunan TBMM hükümeti Anadolu barışı adına faydasız nitelendirmekte ve kesin biçimde protesto etmektedir. ${ }^{\prime \prime 2}$

Ankara Hükümeti Dışişleri Bakanı Yusuf Kemal Bey, Samsun bombardımanı çerçevesinde yayınladığı notayla, Yunan hükümetinin aslında Karadeniz sahilinde yaşayan Rumları yüreklendirmek suretiyle Müslüman halka karşı ayaklandırma amacı güttüğünü ve dolayısıyla işgal ettikleri bölgelerdeki mevcut uyumu bozmak adına Anadolu'da yaşayan iki halkın arasını açmak gibi siyasi gayelerle hareket ettiğini, dünya kamuoyuna iletme fırsatı bulmuştur. İlaveten Yunan hükümetinin böyle eylemlerde bulunmasının Anadolu barışı adına hiçbir biçimde olumlu katkı sağlamayacağının da altını çizmiştir. ${ }^{43}$

TBMM hükümetinin yukardaki protestosu, hem Ankara'nın İstanbul temsilcisi hem de Kızılay'ın İkinci Başkanı Hamid Bey aracılığıyla 10 Haziran 1922 günü yabancı temsilcilere ulaştırılmıştır. Fransız ve İtalyan temsilciler, Yunan donanmasının İstanbul'dan çıkarılmasını istediklerini, bu defa da isteyeceklerini dile getirirken, İngilizler protestonun üzerinde bile durmamıştır. Neticede İngilizlerin böyle hareket etmesinde, Yunanlıları destekleyen ve kışkırtan gücün kendileri olmaları etkili olmuştur. ${ }^{44}$

Açık ve müdafaasız şehir konumunda bulunan Samsun'un bombardımana uğraması vakasını, Türkiye'nin düşmanlarının daha önce Balkanlarda denedikleri hileli eylemlere benzeten ve bu nedenle Türk halkının tuzağa düşmeyeceğini dile getiren İstanbul hükümeti adına İzzet Paşa da mevcut durumu protesto edecektir. ${ }^{45}$ Buradan hareketle İstanbul basını da tıpkı Anadolu basını gibi Samsun bombardımanına tepki göstermiştir. İstanbul basının değerlendirmesiyle, sivil halka yönelik bu bombardımanın amacı, daha önce Balkanlarda denenmiş olan Türkleri Hristiyanlara karşı tahrik etme oyununun yeniden sahneye konulmasından başka bir şey değildir. Ayrıca Ahmet Emin'e göre, diğer bir amaç da ağır vergiler altında inleyen Yunan vatandaşlarının Sakarya Savaşı sonrası içine düştüğü umutsuz bekleyişin acısını ve şiddetini hafifletmekti. ${ }^{46}$ istanbul gazetelerinden Tercüman-ı Hakikat Samsun bombardımanını tamamıyla haksı ve gayrimeşru nitelendirerek, olaya dair tepkisini ortaya koymuştur. Nitekim şehirde, harp malzemelerinin bulunmadığı gerçeği ortaya çıkmıştır. Buradan hareketle Samsun'da bulunan Amerikan Heyeti Azası'nın yaptığı soruşturmada, Yunan filosunun bombardımanı esnasında Samsun'da hiçbir silah

42 Tercüman-ı Hakikat, 26 Haziran 1922, No: 14806, s. 1.

43 Biber, a.g.e., s. 184.

44 Doğanay, a.g.e., s. 113.

45 Hâkimiyet-i Milliye, 12 Haziran 1922, No: 529, s. 1. Samsun bombardımanını protesto eden İstanbul hükümeti, Müttefiklerin İstanbul'da bulunan komiserlerine bu noktada nota vermiştir. Notada, 7 Haziran 1922'de Yunan donanmasının hiçbir tahrik olmadığı halde Samsun şehrini bombardıman etmesi ve yaklaşık beş saat süren bombardıman neticesinde insanca zayiattan başka büyük miktarda maddi zayiat meydana geldiği belirtilerek, açık şehir Samsun'un bombardımana uğramasının uluslararası hukuk ve insaniyet prensiplerini ihlal ettiğini söylenmiştir. İlaveten bombardımanın Anadolu barışı için sarf olunan mesaiyi felce uğrattığını da belirten nota, İstanbul hükümetinin bombardımanı şiddetle protesto ettiğini ve bombardımanın neden olduğu zarar ve ziyandan dolayı hukukunu muhafaza ettiğini ayrıca bu tarzda tecavüzlerin yasaklanması için gerekli tedbirlerin alınmasını hükümetleri adına Müttefik komiserlerinden rica etmiştir; Tercüman-ı Hakikat, 10 Haziran 1922, No: 14791, s. 1.

46 Ahmet Emin, "Samsun Bombardımanı", Vakit, 9 Haziran 1922, No: 1614, s. 1. 
deposunun bulunmadığı ortaya konulmuştur. Soruşturmanın devamında Samsun şehrine 10 kilometre mesafede yer alan (Bafra yöresinde) bir Türk bataryasının bulunmasına rağmen Yunan filosunun ateşine maruz kalmadığı gerçeği de ayrıca belirtilmiştir. ${ }^{47} \mathrm{Bu}$ nedenle basında, bombardımanı, Yunan harp planının değil, siyaset ve propaganda planının uygulanmasına yönelik şeytanca bir hareket biçiminde nitelendiren yazarlar da mevcuttu. Buna göre Yunanlıların amacı, Hristiyanlara zulmedildiği izlenimi verdirerek Batılı devletlerin siyasi çevrelerini ve kamuoyunu Türkiye aleyhine harekete geçirmekti. ${ }^{48}$ Belirledikleri bu plan gereğince Yunanlılar, Samsun bombardımanını göründüğünden başka bir tarafa çevirmek üzere gayret sarf etmişlerdir. İstanbul'da bulunan Yunan temsilcisi, uluslararası hukuk tarafından açık ve müdafaasız şehir kabul edilen Samsun'da yaşanılan hakikatleri başka tarafa çevirip, kendi fena eylemlerini haklı göstermek maksadıyla Rumca gazetelere uzun uzun açıklamalarda bulunmuştur. Yunan temsilcisinin açıklamaları Tercüman-ı Hakikat gazetesinde şu şekilde yer almıştır:

"Yunanlılar Samsun bombardımanını haklı göstermek için şehirde savaş malzemesi bulunduğu hususuna sarılarak hareket etmiş ve bombardıman esnasında kendilerini karşılayan Türk toplarına hedef olduklarını ve hatta uzun çaplı bazı mermilerinin Yunan savaş gemilerine isabet ettiğini söylüyorlar. Yunan filosu kumandanının ültimatomunda belirtilen bir saatlik sürenin dolmasını beklemeden Samsun'u bombardımana başladığı hakkındaki gerçeği de uzatmadan inkâr ederek, ültimatomda yer alan sürenin sona ermesinden sonra bombardımana başladıklarını belirtiyorlar. Hatta arada üç saatlik bir sürenin geçmiş olduğu iddiasında bulunuyorlar. Ancak şehrin süre dolmadan topa tutulduğu bir hakikattir. İstanbul, Yunan temsilcisinin bu garip mektubunu tercüme etmektedir: "Haziranın yedinci günü Yunan filosu Samsun şehrini orada toplanan savaş malzemesi yüzünden topa tutmuştur. Bombardımandan evvel Lahey Konferansı'nın onuncu maddesi gereğince savaş malzemelerinin tahribini ve sivil ahalinin şehirden uzaklaştırılması talep olunmuştur. Yunan filosunun Samsun valisine bir saat süre veren vesikası 248 Nolu Amerikan torpidosunun kaptanı vasıtasıyla tebliğ edilmiştir. Vali Yunan filosu kumandanına verdiği cevapta, Samsun'un müstahkem bir yer olmadığı için hukuken bombardıman edilemeyeceğini belirterek, Yunan kumandanının bütün isteklerini ret etmiştir. Böylece Yunan filosu, valiye verdiği ültimatomun ardından geçen üç saatlik bir süre sonrasında şehri bombardımana başlamış ve özellikle halka ateş açmaktan kaçınmıştır. Bombardıman başlayınca Türk bataryaları, Yunan gemilerine seri ve şiddetli ateş açmışlar, uzun çaplı bazı mermiler Yunan gemilerine isabet etmiştir. Yaşanılan bu gelişme, Samsun şehrinin müdafaasız olduğuna yönelik Türk valisinin iddiasını çürütmekle birlikte, Mustafa Kemal Paşa'nın ordusu için savaş malzemesine sahip bulunduğu gerçeğini de ortaya sermiştir." ilginç olan bu bombardımandan sonra Yunan filosu kumandanı, Amerikan torpidosu kaptanına garip bir mektup göndererek şöyle demiştir: "Şehrin ihtiva ettiği savaş malzemesinden başka toplar ile donanmış bulunduğunu gördüğünüzü ve bundan emin olduğunuzu ümit ederim."'149

Böylece Yunanlıların Samsun bombardımanı olayında Amerikan desteğini göz ardı etmediğini söyleyebiliriz.

Samsun'un bombardımana uğramasının ardından Yunan harekâtı Samsun'dan başka Karadeniz sahili boyunca devam etmiştir. Yunan gemisi Karadeniz sahilinde gördüğü sandal ve takaları batırmaya devam etmiştir. Fransız bandrollü vapurla Karadeniz'den İstanbul'a

47 Tercüman-ı Hakikat, 12 Haziran 1922, No: 14793, s. 1.

48 "Yeni Bir Tahrik-Karlık", ìkdam, 10 Haziran 1922, No: 9063, s. 1.

49 Tercüman-ı Hakikat, 11 Haziran 1922, No: 14792, s. 1. 
gelen bir yolcudan edinilen bilgiye göre, Yunan harp gemileri, Karadeniz'de rast geldikleri sandal ve takaları bombalamakta ve bu araçların mürettebatından ihtiyar olanları en yakın iskelelere çıkarmakta, gençleri ise harp esiri addederek alıp götürmektedir. Buradan hareketle, Giresun açıklarında mısır yüklü bir kaç sandal ve taka batırılmış, mürettebatı ise Giresun'a ihraç edilmiştir. ${ }^{50}$

Türk basını, Samsun bombardımanını askeri değil siyasi nedenlere dayandıırken ve üstelik bombardımanın Anadolu barışını sekteye uğrattığını belirtirken; Yunan basını pekiyi bir iş yaptıklarına inanmış durumdadır. Konstantin'in gazeteleri Samsun bombardımanı eyleminin Yunanlılık adına olumlu bir gelişme biçiminde değerlendirmektedir. Bu doğrultuda yayın yapan gazeteler, daha da ileri giderek, Karadeniz sahilinde taş taş üstünde bırakılmayacak bir vahşetin dahi yapılmasını tavsiye etmektedir. Samsun bombardımanından bahisle, Konstantin taraftarı Patris gazetesi, Ankara'dakiler tarafından tutulan Pontus Rumlarının ihmal edilmesine karşın Yunan toplarının Samsun'u bombardıman ederek cevap verdiğini kamuoyuna bildirmektedir. Gazeteye göre, hem Ankara hem de Bâb-ı Âli bütün dünya milletlerine Samsun bombardımanını şikâyet etse de bu şikâyetleri hiç kimseyi etkilemeyecektir. Dahası, bu eylemi bizzat gerçekleştiren ve özellikle Anadolu'daki emniyet ve askerini takviye etmek isteyen Yunanistan da Türklerin şikâyet ve protestolarından kesinlikle müteessir olmayacaktır. ${ }^{51}$ Venizelos'u destekleyen Tahidromos gazetesi de Samsun bombardımanından dolayı Yunan donanmasını alkışlayacaktır. Gazete; Yunan filosunun faaliyet haberinin, toprağın altında kalan diğer Yunanlıları da temsil ettiğini böylece Rumların ümidini ve Rum ordusunun manevi kuvvetini takviye eylediğini öne çıkarmaktadır. Samsun bombardımanı, geç kalmış bir eylem biçiminde nitelendirmekle birlikte şimdilerde patlayan top seslerinin bir asır devam eden (Kanaris ${ }^{52}$ ten beri) Rum mücadelesinin neticesini teşkil ettiğine değinen gazete, Rumların hemen dehşetli bir mücadeleye girmesinden Kanaris'in torunlarının memnuniyet duyacağını yazmaktadır. İlaveten gazete savaşlarda harap olan Rum yurdu karşılığında Karadeniz sahilinin de baştanbaşa yıkılması gerektiğine vurgu yapmaktadır. Bu durumda "taş taş üstünde bırakılmamalı" dolayısıyla bu eylem, örnek alınacak bir model olmalıdır. Anadolu'daki Hristiyanlara yapılan zulümlere karşın Batı'da yükselen seslerin bir etkisinin görülmediği için bütün Hristiyanların imdadına ancak Yunan donanmasına ait toplarının yetişeceğini aktaran gazete, böylece Anadolu'da sağ kalan birkaç yüz bin Rum'un taze nefes alabileceğini bildirmektedir. ${ }^{53}$

Gazeteler Yunanistan'dan başka Ingiltere'deki gelişmelere de odaklanmıştır. Buna göre Hâkimiyet-i Milliye gazetesinin İstanbul'dan aldığı bilgi, İngiliz Avam Kamarası'nda Samsun bombardımanının ele alınmasıyla ilgilidir. Avam Kamarası azasından bir yetkili, İngiliz hükümetinin Samsun bombardımanından haberdar olup olmadığını ve Yunan donanmasının ne şekilde Boğazlar üzerinden Samsun'a çıktığını sormuş, bunun üzerine Dışişleri Bakanlığı Müsteşarı, şu cevabı vermiştir:

50 Tercüman-Hakikat, 19 Haziran 1922, No: 14799, s. 1.

51 Hâkimiyet-i Milliye, 15 Haziran 1922, No: 532, s. 1.

52 Konstantinos Kanaris; Yunan Bağımsızlık Savaşı’nda (1821-1829) ünlenmiş devlet adamı ve deniz subayıdır. Savaş sırasında Yunan donanmasına kendi gemisiyle katılmış, yangın gemilerini başarıyla kullanmasından dolayı kısa zamanda ün kazanmıştır. Kanaris, Türklerin kontrolü altındaki denizde cesur ve cesaretli olma özellikleriyle öne çıkmıştır. https://en.wikipedia.org/wiki/Constantine_Kanaris, (IGT: 04.09.2019); George J. Leber, The 1821 Greek War Of Independence and America's Contributions To The Greek Cause, Order of Ahepa, Washington 1971, p. 10-11.

53 Hâkimiyet-i Milliye, 15 Haziran 1922, No: 532, s. 1. 
"Evet, Samsun'un Yunan donanması tarafından bombardıman edildiğinden haberdar bulunuyoruz. Yunanlıların bu bombardımandan maksatları son zamanlarda Rusya'dan getirilen ve Samsun'da saklı tutulan savaş malzemelerinin tahribidir. Bu bombardıman esnasında savaş malzemesi dışındaki eşyanın tahribinden hükümetin haberi yoktur. Yunan donanmasının Karadeniz'e çıkmasına gelince, 1921 Ağustos'undan beri Müttefiklerce, Boğazlar mıntıkasında oluşturulan bitaraflık kapsamında Yunan gemilerinin Boğazlardan çıkışına engel olamayız." ${ }^{\prime 54}$

Hâkimiyet-i Milliye gazetesi Dışişleri Bakanlığı Müsteşarı'nın sözlerini değerlendirirken, bombardıman hakkında bilgi veren müsteşarın büyük bir Yunan taraftarlığıyla işi idare ettiğine vurgu yapmaktadır. İlaveten gazete, İngiliz hükümetinin Samsun'da cephane bulunduğunu iddia edecek kadar bilgi sahibi bulunduğunu belirtmesinin ardından tahribattan hiç haberdar olmamasını garipsemektedir. Nitekim Samsun'da tek bir sandık cephane bile patlamamıştır. Dolayısıyla savaş malzemeleri değil, şunun bunun yani zavallı halkın meskenleri tahrip edilmiştir. Bu açıdan İngiliz dış siyasetini eleştiren gazete, Samsun bombardımanının İngiltere' nin bilgisi dâhilinde yapıldığından yola çıkarak, bütün dünyanın, yabancıların, Yunanlıların Samsun'a ne maksatla geldiklerini top atışlarından anladıklarını belirtmektedir. ${ }^{55}$

Diğer taraftan İstanbul basınında, bombardıman eylemini ileri taşıyarak Ankara'yı dahi suçlu gösterenler de yok değildi. Bu bağlamda muhalif Ali Kemal, Samsun bombardımanında Yunanlıların suçu olduğu kadar Yunanistan ile Türkiye arasındaki düşmanlığı Avrupa ve Hristiyanlık âlemi ile bir sorun, bir zıddiyet haline dönüştüren Ankara'ya ait olduğunu iddia etmiştir. ${ }^{56}$

Samsun bombardımanı basının yanı sıra, 8 Haziran 1922 tarihli TBMM oturumlarında da gündeme gelmiştir. Samsun bombardımanı ile alakalı olarak, Vekiller Heyeti bölgede sıkıyönetim ilan edilmesi için meclise tezkere sundu. Tezkere bağlamında Çorum Milletvekili Dursun Bey, memleketin 10-15 seneden beri fevkalade şartlar geçirdiğini ve bu nedenle askeri mahkemelerle idare edildiğinden bahisle Samsun bölgesinde sıkıyönetimi gerektirecek bir durumun mevcut bulunmadığını belirtmiştir. Ayrıca sıkıyönetimin Samsun dışında asayişsizliği ortadan kaldırmayacağını belirten Dursun Bey şunları söylemiştir:

“Tokat'tan Samsun'a kadar devam eden bölgede pek çok köylerimiz tahrip ediliyor. Rica ederim, Tokat köyleri yanarken, Zile köyleri yanarken Samsun'daki sıkı̈önetim acaba bunların önünü alacak mıdır ve bu tedbir yeterli midir? Bundan dolayı Samsun'da sıkıyönetime gerek yoktur. Yapılacak tedbir jandarmamızı, takip müfrezelerimizi harekete geçirerek asayişsizliğin önüne geçmektir. Samsun'da yeni yaşanan olay sıkıyönetimi gerektirmez. Yaşanılan durum geçici bir meseledir. Bundan dolayı Vekiller Heyeti'nin kararını kabul etmemenizi rica ederim."

Dursun Bey'den sonra söz alan Hakkari milletvekili Mazhar Müfit Bey de Dursun Bey'i destekleyen biçimde konuşmuştur:

"Olağanüstü sıkıyönetim geçici şekilde oluşturulur. Samsun'da yeni gelişen durum sıkıyönetim gerektirecek bir durum değildir. Gazetelerde gördügümüz kadarıla Yunan filosu orayı bombardıman etmiş. Biz isterdik ki sıkıyönetim teklifinden önce sıkıyönetimi gerektiren durum hakkında vekiller bizi aydınlatsınlar. Aksi takdirde bir sıkıyönetime karar

54 Hâkimiyet-i Milliye, 21 Haziran 1922, No: 537, s. 1.

55 Hâkimiyet-i Milliye, 21 Haziran 1922, No: 537, s. 1.

56 Ali Kemal, “Ne Vahşiyane Bir Hareket”, Peyâm-ı Sabah, 11 Haziran 1922. 
veremeyiz. Sıkıyönetime karar vermek için Samsun'da meydana gelen hadiseler hakkında burada Vekiller Heyeti bize bilgi vermelidir. Dünkü bombardımanı bugünkü gazetelerden anladık, hadiseler hakkında bilgi isteriz. Bu bilgi verilmedikçe sıkıyönetim müzakere edilemez. ${ }^{157}$

Bu iki vekilin Samsun'da yaşanılanların sıkıyönetimin gerektirmeyeceğini dile getirmesi üzerine İstanbul milletvekili ve İçişleri Bakanı Ali Fethi Bey, Samsun bombardımanı hakkında yaşanılanlarla ilgili Erkan-ı Harbiye-i Umumiye Vekili Fevzi Bey'in meclis oturumunda izahat vereceğini ancak "ansızın" rahatsızlanması nedeniyle kendisinin izahatta bulunacağını söylemiştir. Ali Fethi Bey 8 Haziran tarihli gazetelerde görüldüğü üzere 7 Haziran sabahı, Samsun limanına gelen Yunan donanmasının öğleden sonra üç sularında yaklaşık iki saat süreyle şehri bombardıman ettiklerini söyleyerek sıkıyönetim meselesine şöyle değinmiştir:

"Sabahleyin limana gelmiş olan gemilerin elbette düşmanca ve saldırgan bir biçimde hareket için gelmiş bulunduklarını gerek kumandan ve gerekse vali anlıyorlar. Harekât bir bombardıman ile ya da ihraç ile neticelenebilirdi. Bu itibarla, Yunan donanması amirali verdiği süre içerisinde şehirdeki bütün savaş malzemesinin tahrip edilmesini verdiği ültimatomda dile getirmiş aksi durumda Ikinci Lahey Konferansının onuncu maddesini uygulayacaklarını söylemiştir."

Daha sonra basında da geçtiği şekliyle Yunan Donanması Kumandanının bir Amerikan torpidosu vasıtasıyla Samsun valisine ilettiği ültimatom ile valinin Yunan amiraline verdiği cevap hakkında meclise bilgi sunan Ali Fethi Bey, Samsun bombardımanı neticesinde ortaya çıkan hasarı belirtmiştir. Bu doğrultuda İçişleri Bakanı Ali Fethi Bey saldırıyla ilgili mecliste yaptığı açıklamalarda hükümetin bölgede sıkıyönetim ilan ederek olumsuz herhangi bir olayın yaşanmasının önüne geçeceğini belirtmiştir. Sıkıyönetimin, zaten güçlükle sağlanan Türk müdafaasını, daha sükûnetle idare ve tanzim edebilmek ve şehir içerisinde her türlü fena duruma meydan vermemek maksadıyla yapılacağını izah eden Ali Fethi Bey, böylece tehlike geçince sıkıyönetimin sona ereceğinden söz etmiştir. ${ }^{58}$ Neticede Samsun'da sıkıyönetim ilânına dair İcra Vekilleri Riyasetinin hazırladığı tezkere müzakere edilmiş ve sıkıyönetimin on beş gün süre ile Samsun merkez kazasında uygulanması kabul edilmiştir. ${ }^{59}$ Samsun merkez kazasında ilan edilen sıkıyönetim, İcra Heyeti Vekilleri Heyeti'nce 22 Haziran günü yürürlüğe girmek üzere 21 Haziran 1922'de kaldırılmıştır. ${ }^{60}$

\section{İngiliz Avam Kamarası Zabıtları Üzerinden Samsun Bombardımanı}

Türk basını Samsun bombardımanı meselesinin İngiliz Avam Kamarası'nda ne şekilde ele alındığını da takip etmiş ve bu anlamda elde ettiği bilgileri kamuoyuna ulaştırmıştır. Dolayısıyla Samsun bombardımanı meselesi, İngiliz Avam Kamarası müzakerelerine konu olmuştur. Müzakerelerde, İngiliz hükümetinin Anadolu barışına dair artan mesaisi göz önüne serilirken, diğer taraftan Samsun bombardımanını gerçekleştiren Yunan gemilerinin eylemini Boğazlardan geçerek gerçekleştirmesi dikkatten kaçmamıştır. Nitekim Mr. Herbert, Dışişleri Bakanlığı Müsteşarı'na, Yunan donanması tarafından Samsun'un bombalanmasına yönelik bilgi verilip verilmediğini, savaş malzemeleri dışında bir tahribat olup olmadığını ve Müttefik kuvvetler tarafından ilan edilen Boğazlar ve Çanakkale

57 TBMM Zabıt Ceridesi, 1. Dönem, 20. Cilt, 50. Birleşim, 08.06.1922, s. 232-233.

58 TBMM Zabıt Ceridesi, 1. Dönem, 20. Cilt, 50. Birleşim, 08.06.1922, s. 233-244.

59 TBMM Zabıt Ceridesi, 1. Dönem, 20. Cilt, 51. Birleşim, 10.06.1922, s. 310; Türkiye Cumhuriyeti Cumhurbaşkanlığı Devlet Arşivleri Başkanlığı Cumhuriyet Arşivi (BCA), Fon No: 30-18-1-1-, Yer No: 5-17-20.

60 BCA, Fon No: 30-18-1-1, Yer No: 5 - $18-15$. 
bölgesinin tarafsız bölge olmasına rağmen, Yunan filosunun eylemi ve Müttefiklerin rızası hakkında herhangi bir açıklama yapıp yapmayacağını sormuştur. Bu soruya karşılık İngiliz Dışişleri Bakanlığı Müsteşarı Harmsworth, Samsun bombardımanından haberdar bulunduğunu ve bombardımanın amacının Samsun limanına Rusya'dan gelen savaş malzemesinin imhası gibi göründüğünü söyleyerek, savaş dışı olan hedeflerin ve mülkün tahrip edildiğine dair İngiliz hükümetinin hiçbir bilgiye sahip bulunmadığını belirtmiştir. Ayrıca Harmsworth, 10 Ağustos ${ }^{61}$ tan bu yana Müttefikler tarafından sürdürülen Boğazlar bölgesinin tarafsızlı̆ıının, Yunan-Türk çatışması esnasında da devam ettiğini ve dolayısıyla savaşan taraflara ait gemilerin bu sulardan geçişini etkilemediğini belirterek, Müttefiklerin, Yunanistan'ın mevcut bombardımanı gerçekleştirme niyetinden haberdar edilmediklerini ve buna rıza gösterdiklerine dair hiçbir göstergenin mevcut olmadığını kaydetmiştir. Devamında Herbert, "Eğer silahlı güçlerin böyle tarafsız bir bölge olarak adlandırılan bir yere girmelerine müsaade edilirse o zaman "tarafsızlık" ne demektir?" şeklinde bir soru yöneltmesinin ardından Harmsworth, gerçek durumla ilgili uygun yorumu yaptığını ve eğer isterse Herbert'in daha fazla bilgi için yazılı bir soru verebileceğini söylemiştir. Ardından can alıcı soru Mr. Malone tarafından dile getirilmiştir ki bu soru Samsun bombardımanında kullanılan mermilerin İngiliz mermisi olup olmadığına dairdir. Harmsworth, bunun ihtimal dışı olduğunu düşündüğünü söylemesinin yanı sıra bu konuda bir bilgisinin bulunmadığını da parlamentoya bildirmiştir. ${ }^{62}$

Anlaşılacağı üzere, Samsun bombardımanı olayının Avam Kamarası'nda ele alınması söz konusudur. Bu bağlamda dönemin basınının da Avam Kamarası müzakerelerini kendi kamuoyuna ulaştırdığı anlaşılmaktadır. İngiliz Avam Kamarası'nın 14 Haziran tarihli oturumu, Tercüman-ı Hakikat gazetesinde yerini almıştır. Buna göre, azadan Mr. Herbert, Samsun bombardımanı hakkında hükümetten izahat istemiş, hükümet adına da Dışişleri Bakanlığı Müsteşarı Harmsworth söz alarak olayı şöyle değerlendirmiştir:

“Gerçekte Yunan donanmasının Samsun'u topa tutması hükümetin dikkatini çekmiştir. Belki de bu taarruzdan maksat Rusya'dan Samsun'a ulaşan mühimmatın tahribiydi. ingiltere hükümeti çevredeki halka ait meskenlerin tahrip olmasından haberdar değildi. Geçen 10 Ağustos'tan beri Türk-Yunan muharebesi nedeniyle Müttefiklerce Boğazlar mıntıkasında oluşturulan bitarafık, muharip gemilerin mezkûr sulardan geçmesine mani değildir. Yunanistan'ın Samsun'u bombardıman etmek maksadında bulunduğu Müttefiklere ihbar olmamıştır. Bu konuya Müttefiklerce uygunluk gösterilmemiştir. "63

19 Haziran 1922 tarihli oturum, Kıdemli Yüzbaşı Kenworthy, Dışişleri Bakanlığı Müsteşarı'na Samsun'un ve Pontus sahilindeki diğer şehirlerin Yunan savaş gemileri tarafından bombalanması konusunda herhangi bir bilgiye sahip olup olmadığını, siviller arasında herhangi bir zayiatın bulunup bulunmadığını, herhangi bir Amerikan malının bombardıman sırasında zarar görüp görmediğini ve Amerikan ile diğer Avrupa vatandaşlarının ölüp ölmediğini veya yaralanıp yaralanmadığını sormuştur. Harmsworth, İngiliz hükümetinin Pontus sahilindeki şehirlerin bombardımanı hakkında hiçbir bilgi edinmediğini ayrıca Samsun bombardımanı ile ilgili hiçbir detaya sahip bulunmadığını söyleyerek, bu konuda daha fazla bilgi sahibi olmayı umduğunu belirtmiştir. Ayrıca

6110 Ağustos 1921 tarihinde Paris'te toplanan Yüksek Konsey, Türk-Yunan savaşı hakkında alınan tarafsızlık kararını katı bir şekilde uygulamaya karar vermişti. Müttefikler, taraflar arasındaki çatışmalara, asker, silah veya borç ne olursa olsun yardım etmeyecekler, müdahalede bulunmayacaklardı; Abdurrahman Bozkurt, "itilaf Devletleri'nin Türk-Yunan Savaşı'nda Tarafsızlık İlanı (13 Mayıs 1921)”, Atatürk Araştırma Merkezi Dergisi, C. XXVI, S. 76, Ankara 2010, s. 47.

62 SAMSUN (BOMBARDMENT), HC Deb 14 June 1922 vol 155 cc337-8; The Times, 15. 06. 1922, s. 18.

63 Tercüman-ı Hakikat, 20 Haziran 1922, No: 14800, s. 1. 
Kenworthy'nin bu meseleyle alakalı yazılı bir soru vermesi durumunda, ona daha fazla bilgi vermeye çalışacağını da ilave etmiştir. ${ }^{64}$

20 Haziran 1922 tarihli oturumda, Karadeniz kıyılarında bulunan Türk şehirlerinin Yunanlılarca bombalanması üzerine İngiliz hükümetinin takınacağı tavra odaklanan Kenworthy bu kez, İngiliz hükümetinin Yunan hükümetiyle iletişime geçip geçmediği konusunda bilgi sahibi olmak istemiştir. Bu soru karşısında, İngiliz hükümetinin Samsun bombardımanına ilişkin bakış açısını aktaran Dışişleri Bakanlığı Müsteşarı Harmsworth, bu bombalamada Yunanlıların teknik olarak mazur görünebileceğini ancak yaşanılan bombardımanın Anadolu barışına zarar verebilme ihtimalinden dolayı İngiliz hükümetinin derin üzüntü duyduğunu ve böyle bir bombardımanın tekrarlanmaması için, Yunan hükümetinin bilgilendirilmesi adına gerekli adımları attıklarını söylemiştir. Bu açıklama karşısında Kenworthy, Harmsworth'e teşekkür ederek açıklamanın oldukça tatmin edici olduğunu ilave etmiş ve ardından Boğazlar ve Boğaziçi'nden geçen bu Yunan savaş gemileri üzerinde bazı kontrol uygulamalarının mümkün olup olmadığını sorması üzerine Harmsworth, daha önce yaptığı açıklamaya başka bir şey ilave eklememeyi tercih ettiğini belirtmiştir. ${ }^{65}$

21 Haziran 1922'deki oturumda Kenworthy, Dışişleri Bakanlığı Müsteşarı'na Boğazların Ingiliz savaş gemilerinin kontrolünde olup olmadığını, bütün ulusların savaş gemilerinin Boğazlardan geçmesine izin verilip verilmeyeceğini ve İngiliz hükümetinin Karadeniz sahilindeki Türk şehirlerini bombalamak niyetiyle hareket eden Yunan savaşgemilerinin son zamanlarda Boğazlardan geçtiğinden haberdar olup olmadığını sormuştur. Harmsworth de Boğazlardaki savaş gemilerinin kontrolünün İngilizlerce değil Müttefiklerin denetimi altında sağlandığını ve Boğazların, Türk ateşkesiyle bağdaşmayan durumlar dışında, tüm ulusların savaş gemilerine açık olacağını söylemiştir. Son soru için Harmsworth'in cevabı, bu soruyu daha önce açıkladığına dairdir. ${ }^{66}$

21 Haziran 1922 tarihli oturumda, yine Kenworthy, Dışişleri Bakanlığı Müstaşarı'na, Yunan savaş gemileri tarafından Samsun ve Pontus sahilindeki diğer yerleşim yerlerinin bombalanmasıyla ilgili herhangi bir bilgi sahibi; siviller arasında herhangi bir zayiatın olup olmadığını ve herhangi bir Amerikan malının bombardımandan zarar görüp görmediğini sormuştur. Dahası Amerikan veya diğer Avrupa vatandaşlarının öldürülüp öldürülmediğini veya yaralanıp yaralanmadığını da sormuştur. Böylece Kenworthy daha önce sorduğu ve cevap alamadığı soruyu Avam Kamarası'nda yeniden dile getirmiştir. Dışişleri Bakanlığı Müsteşarı Harmsworth da İngiliz hükümetinin, Samsun'dan başka herhangi bir bombardıman hakkında resmi bir bilgiye sahip bulunmadığını söylemiştir. Ardından İngiliz hükümetine, Ankara'daki TBMM'den ve İstanbul'daki Türk hükümetinden gelen protestolar çerçevesinde, Samsun'da sivil mülkte can kaybı ve zararın olduğunun anlaşıldığını, ancak bu protestolarda ayrıntı verilmediğinden İngiliz hükümetinin başka hiçbir bilgisi olmadığını belirtmiştir. ${ }^{67}$

22 Haziran 1922'deki oturumda, Mr. Herbert, Başbakana, İngiliz hükümeti uzlaşma şartlarını İzmit'te Mustafa Kemal Paşa ile hemen ele alacak mı diye sormuştur. Harmsworth da Paris Konferansı tasarısının Yakın Doğu sorununun çözümüne yönelik önerilerinin,

64 GREECE AND TURKEY, HC Deb 19 June 1922 vol 155 cc816-7.

65 TURKEY AND GREECE, HC Deb 20 June 1922 vol 155 cc1036-7.

66 BOSPHORUS (NAVAL CONTROL), HC Deb 21 June 1922 vol 155 c1279.

67 SAMSUN (BOMBARDMENT), HC Deb 21 June 1922 vol 155 cc1279-80. 
Yunan hükümeti ve İstanbul ile Ankara hükümetlerine iletildiğini ve ilgili taraflardan her biri ile ayrı bir tartışma olamayacağını söylemiştir. ${ }^{68}$

26 Haziran 1922'deki oturumda, Kenworthy, Dışişleri Bakanlığı Müsteşarı'na yakın zamanda Yunan savaş gemileri tarafından Samsun'un bombardımanında sivil şahıslara ve onların mülklerine verilen zararın ayrıntılarını alıp almadığını; aldıysa toplam kaybın ne kadar olduğunu sormuştur. Harmsworth verdiği cevapta, İstanbul'da bulunan İngiliz Yüksek Komiseri'nden gelecek rapor sayesinde bilgi edinebileceklerini belirtmiştir. Bunun üzerine Kenworthy de "Bana o bilgiyi verin, yoksa gelecek hafta bugün aynı konuda ayrı bir yazılı soru vereceğim"69 demiştir.

$\mathrm{Bu}$ arada başka bir mesele gündeme geldi. Bu, Mustafa Kemal Paşa'nın İzmit ziyaretinde söylediği nutukla ilgilidir. Mustafa Kemal Paşa'nın bütün cihana hitap eden konuşması orada hazır bulunan kalabalık tarafından heyecanla alkışlanmıştır. Mustafa Kemal Paşa konuşurken kalabalık halk kitlesi: "kahrolsun zulümler, yaşasın mazlum ve müstakil Türkiye!" şeklinde coşkulu biçimde bağırmıştır. ${ }^{70}$ Mustafa Kemal Paşa, İzmit konuşmasında, 1921'de İnebolu'yu, yakın zamanda da Samsun'u bombardıman ettiren gücün, Türkiye'nin mübarek topraklarına saldırttığı düşmanı takviye ve teşvik eden ancak diğer taraftan dünyanın en bitaraf hükümeti gibi görünen İngiltere olduğunu üstü kapalı bir biçimde dile getirmiştir. Batı'nın bazı hükümetlerinin Türkiye ile hesaplaşmaktan çıkmak istemediği için düşmanlık durumunun devam ettirildiğine değinen Mustafa Kemal Paşa, patlamak üzere düşmanları teşkil, teçhiz ve teşvik eden faillerin, Türkiye'de Ankara değil Atina'da ve belki de büyük bir başkentte aramak lazım geldiğini söylemiştir. Ardından Anadolu'da subaylarını dolaştıran ve tahkikat icrasını ileri sürerek diğer hükümetleri de bu teşebbüse katmak imkânını kollayan İngiltere'nin hareketlerini mantıksız değerlendiren Mustafa Kemal Paşa, dünyada müstakil hiçbir devletin kendi içişlerine dostları şöyle dursun, düşmanlarını bile kesin biçimde karıştırmayacağına dikkat çekmiştir. Müstakil yaşamış ve istiklalin aşığı olan Türkiye halkının ve devletinin istiklalini tanımamak ve tanıtmamak isteyen hükümetlere karşı, TBMM hükümetinin milletten aldığı meşru yetkilerle, müstakil devlet ve milletin mevcudiyetini ve istiklalini temin etmek üzere misliyle mukabele edeceğini belirten Mustafa Kemal Paşa, Türk milletinin imhaya değil sadece ihyaya layık bulunduğunu öne çıkarmıştır. Bu kapsamda bütün cihana seslenen Mustafa Kemal Paşa, Türk milletinin idama ve imhaya karşı mücadele ederek, esir olmaya rıza göstermeyeceğine dikkat çekerek, İngiliz ricalinin içinde bulunduğu gafleti, tüm dünyanın dikkatine sunmuştur. Bu bağlamda, TBMM hükümetinin bütün hesaplardan alnı ak çıkacağına şüphe duymayan Mustafa Kemal Paşa, yine TBMM hükümetinin gerçekleştirdiği icrââtlardan da tüm dünyaya hesap vermekten biran bile tereddüt etmeyeceğini açık biçimde ifade etmiştir. ${ }^{71}$

Mr. O'connor, Dışişleri Genel Sekreterliği'ne, 20 Haziran'da İzmit'te Mustafa Kemal Paşa'nın, nutkundan haberdar olup olmadığını sormuştur. Mustafa Kemal'in konuşmasında, İngiliz hükümetinin Türkiye'ye yönelik politikasını şiddetli biçimde eleştirdiğini ve Türklerin, Yunanlılara karşı işlediği vahşeti askeri nedenlerle haklı göstererek, İtilaf devletlerinin rızasıyla İngiliz hükümetinin yapmaya karar verdiği soruşturmaya katılmayacağını resmi biçimde açıkladığını aktaran O'connor, İngiliz hükümetinin bu meydan okumaya nasıl karşılık vereceğini sormuştur. Harmsworth de Mustafa Kemal'in konuşmasının basındaki

68 NEAR EAST, HC Deb 22 June 1922 vol 155 c1496.

69 GEREECE AND TURKEY, HC Deb 26 June 1922 vol 155 cc1650-1.

70 Tercüman-ı Hakikat, 20 Haziran 1922, No: 14800, s. 1.

71 Hâkimiyet-i Milliye, 20 Haziran 1922, No: 536, s. 1. 
versiyonunu gördüğünü dolayısıyla O'connor'in genel itibariyle Mustafa Kemal'in konuşmasını özetlediğini ancak bu konuşmanın soruşturma komisyonunu reddine dair bir atıf içermediğini bu nedenle İngiliz hükümetinin özel veya farklı bir tavır alma durumunun bulunmadığını söylemiştir. Bunun üzerine, Mr. Cecil'in, Dışişleri Bakanlığının bu komisyonun devam etmesine izin verilip verilmeyeceği hakkında bilgi sahibi olup olmadığını sorması üzerine, Harmsworth, bu konuda tam olarak emin olmadığını ancak beyefendinin yazılı bir soru verebileceğini belirtmiştir. ${ }^{72}$

Samsun bombardımanı meselesini araştırmak üzere kurulacak bir komisyondan bahsedilirken bir İngiliz milletvekili konu ile alakalı, oluşturulacak araştırma komisyonunun birtaraf ülkelerden kurulmasını istemiştir. Daily Telgraf gazetesi Avam Kamarası azasından Kenworthy'nin bu konuyla ilgili mektubunu kamuoyuna sunmaktadır:

"Ben Türkler ile Yunanlıların masum veya suçlu olduklarını söylemiyorum, ben, İsveçliler, isviçreliler, Danimarkalılar ve ispanyollardan kurulu bitaraf araştırma komisyonunun teşkil edilmesi lehinde bulunuyorum. Bu heyette Türk ve Rum tercümanlar bulunmalıdır. Ben soruşturma komisyonuna Müslüman azanın dâhil edilerek, onlara bağlı Hintlilerin teklifine iştirak etmiyorum. Zira bunlar Türkler aleyhinde rey vermeyeceklerdir." ${ }^{\text {"73 }}$

28 Haziran 1922'deki parlamento oturumunda Mr. Malone, Dışişleri Bakanlığı Müsteşarına, İngiliz hükümetinin, Müttefik Büyük Güçler tarafından ilan edilen İstanbul bölgesinin tarafsızlığıyla ilgili Ankara hükümetinden bir protesto alıp almadığını ve Yunanistan'ın Karadeniz'deki Türk limanlarına karşı saldırgan eylemleri için İstanbul limanını bir deniz üssü olarak özgürce kullandığına dair Ankara hükümetinin, İngiliz hükümetinden, şikâyetçi olup olmadığını sormuştur. Ardından ise İngiliz Hükümetiınin bu eylemin devam etmesine izin verip vermeyeceğini veya hangi adımlar atacağını sorusuna ilave etmiştir. Harmsworth verdiği cevapta, İngiliz hükümetinin, Ankara hükümetinden bir protesto ${ }^{74}$ aldığını ancak protestonun İngiltere'nin yanı sıra Fransız ve İtalyan hükümetlerine de gönderilmesinin Müttefikler arasında ortak karar alınmasını kaçınılmaz kıldığını söylemiştir. Bunun üzerine Mr. Malone, Müttefik devletlerin ortak eyleminin ne olacağını sorması üzerine Harmsworth, henüz böyle bir ortak eylem üzerinde düşünüldüğünü belirtmiştir.

Konuşmanın arasına giren Kenworthy bu kez, Yunan savaş gemilerinin İstanbul'u üs olarak kullandıklarının doğru olup olmamasını sorması üzerine, Harmsworth, ancak cesur bir üyenin bu konu ile alakalı resmi bir soru sorabileceğini belirtmiştir. ${ }^{75}$

29 Haziran 1922 tarihli oturumda ise Mr. Herbert, Dışişleri Bakanlığı Müsteşarı́na, Samsun'u bombalayan Yunan zırhlılarının üssünün tarafsız sularda mı yoksa Atina'da mı bulunduğunu sormuştur. Mr. Harmsworth, İngiliz hükümetine gelen bilgiler doğrultusunda, bombardımanda kullanılan Yunan zırhlılarının, İstanbul'dan Samsun'a gittiğinin anlaşıldığını belirtmiştir. ${ }^{76}$

72 GREECE AND TURKEY, HC Deb 26 June 1922 vol 155 cc1650-1.

73 Tercüman-ı Hakikat, 14 Haziran 1922, No: 14795, s. 1.

74 The Times gazetesinin 24 Haziran 1922 tarihinde Yakın Doğu muhabirinden aldığı habere göre Ankara Hükümeti, yakın zamanda Samsun'u bombalayan Yunan filosunun üs olarak İstanbul'daki Türk karasularını kullanması nedeniyle Müttefik Yüksek Komiserliğini protesto etmiştir. Nota ayrıca, Türk-Yunan savaşında resmi olarak tarafsız olmalarına rağmen İtilaf Devletlerinin bu eyleme göz yummasından ve buna ilave olarak, Türk gemilerinin, Karadeniz'deki İngiliz savaş gemileri tarafından ve ardından İtilafıın bu yönde yaptığı açıklamalarla durdurulmasından da şikâyetçi olmuştur. The Times, 26. 06. 1922, s. 7.

75 GREECE AND TURKEY, HC Deb 28 June 1922 vol 155 cc2036-7.

76 SAMSUN (BOMBARDMENT), HC Deb 29 June 1922 vol 155 c2331W. 
Avam Kamarası müzakerelerine, olayın sıcaklığı bağlamında, haziran ayı boyunca sık sık dâhil olan Samsun bombardımanı olayı temmuz görüşmelerine de kısmen gündeme gelmiştir.

12 Temmuz 1922'de gerçekleşen İngiliz Parlamentosu'ndaki görüşmelerde, Kenworthy, Dışişleri Bakanlığı Müsteşarına, yakın zamanda Yunan savaş gemileri tarafından Samsun'da gerçekleştirilen bombardımanda sivillere ait mülklerinin zarar görüp görmediğine ilişkin ayrıntı alıp almadığını; ölü veya yaralı sivillere dair toplam kaybın ne kadar olduğunu sormuştur. Dışişleri Bakanlığı adına söz alan bakanlık müsteşarı Mr. Harmsworth, İstanbul'daki İngiliz Yüksek Komiseri'nden henüz yeni alınan bir rapora göre, 7 Haziran Samsun bombardımanın sonucunda, dört kişinin öldüğü ve üç kişinin de yaralandığını parlamentoya bildirmiştir. Ancak ölen veya yaralan kimselerin uyruklarına dair hiçbir bilgi mevcut olmadığını bildiren Harmsworth, maddi hasar bağlamında önemli miktarda benzin ve gazyağı (kısmen Amerikalılara ait) içeren benzin deposunun, hükümet konağı ile gümrük dairesinin bir kısmının zarar gördüğünü konuşmasına ilave etmiştir. Ayrıca Türk basınından elde ettiği bilgi doğrultusunda Harmsworth, bombardıman neticesinde 20 Müslüman, 15 Rum ve 13 Ermeni'nin evininin yıkıldığını belirtmiştir. Bu kez, Mr. Malone, Dışişleri Bakanlığı Müsteşarı'na, İstanbul'un üs olarak kullanılmasına hala izin veriyor muyuz? biçiminde sorduğu soruyla, İngiltere'nin Samsun bombardımanında nerede durduğunu öğrenmek istemiştir. Harmsworth'da "Bu, ortaya çıkmayan büyük bir soru" şeklinde cevap vermiştir. ${ }^{77}$

Anadolu'daki gelişmeleri merak eden Avam Kamarası, İngiliz hükümetinin, Ankara hükümetiyle irtibat kurup kurmadığını öğrenmek istemektedir. Ancak parlamentoda, "gelişmeler ne durumda" şeklindeki sorulara, "önceki cevaplara bak" biçiminde cevaplar verilmiştir. ${ }^{78}$

\section{Samsun Bombardımanı ve Anadolu Barışı}

Samsun'da Yunan donanmasının gerçekleştirdiği bombardımanın, Anadolu barışına zarar verdiği biçimindeki yorumlar hem Türk basınında hem de İngiliz Avam Kamarası Zabıtlarında söz konusudur. Buradan hareketle, Samsun bombardımanı vakasını Paris siyasi çevrelerine dayandırarak yorumlayan Tan gazetesi, Paris'teki yetkililerin Anadolu barışından umutlu bulunmadığının altını çizmektedir. Bu konu Tercüman-ı Hakikat gazetesinde şu şekilde değerlendirilmektedir:

"Tan gazetesi Samsun'un Yunan filosu tarafından bombardımanından bahsettiği sırada, Yunan başkumandanlığında meydana gelen değişmenin, harp ilanını doğurduğunu ve Müttefiklerin Türk-Yunan olaylarını uyanıklıkla takip etmeleri gerektiğini söyleyerek, yakın bir zamanda Türk-Yunan barışının muhtemel görülmediğini açığa vurmuştur. Ilaveten, muharipler arasındaki münasebet, gerginliğin artmasıyla bir çarpışmaya dönüşebilir."

Yine Tan gazetesi, Paris siyasi çevrelerinin, Türk-Yunan münasebetlerini yakından takip ettiğini ve Anadolu barışı ümitlerinin hayal ve Müttefiklerin barış lehindeki son tespitlerinin ise neticesiz olduğunu bir defa daha kamuoyuna yansıttığını belirtmektedir. ${ }^{79}$ Tan gazetesinin Anadolu barışının imkânsız bulması Hâkimiyet-i Milliye gazetesinin de ilgisini çekmiştir. Ayrıca, bombardımandan kaynaklı olarak var olan gergin bir ortamda,

77 SAMSUN (BOMBARDMENT), HC Deb 12 July 1922 vol 156 cc1198-9.

78 GREECE AND TURKEY, HC Deb 10 July 1922 vol 156 cc865-6W.

79 Tercüman-ı Hakikat, 11 Haziran 1922, No: 14792, s. 1. 
Yunan-Türk barışının yakında imzalanacağına dair hiçbir işaretin bulunmadığını aktaran Tan gazetesinin Paris'ten şu telgrafı gönderdiği bildirilmektedir:

"Paris yetkili siyasetçileri Türk-Yunan düşmanlığını yakından takip etmektedir. Anadolu barışını ümit etmek boşuna bir hayaldir. Ancak yine de Anadolu barışı lehinde hareket eden itilaf devletleri arasında devam eden mesai, ümit vericidir." ${ }^{\prime 80}$

Diğer taraftan Samsun bombardımanı sıcaklığını korurken, TBMM'nin barış görüşmeleri için Yunanistan'a başvuruda bulunduğuna dair söylemler öne çıkmaya başlamıştır. Bu konuda Erzurum mebusu Hüseyin İzzet Bey, TBMM hükümetinin, Anadolu barışı için Yunanistan'a müracaatta bulunduğuna dair çıkan söylentiyi dile getirmesi üzerine Dışişleri Bakanı Yusuf Kemal Bey şu cevabı vermiştir:

"Hükümetimiz adına hiçbir şahıs böyle bir müracaatta bulunmamıştır. Biz harp için harp etmiyoruz. Bütün emel ve hedefimiz milli bağımsızlığımızı elde etmektir. Kudretimiz, maksadımızı gerçekleştirmekte yeterlidir. Bu bakımdan Yunanlılar bizimle doğrudan doğruya anlaşmak istiyorlarsa bize müracaat etsinler. ${ }^{\prime 81}$

İstanbul basınının verdiği bilgi yine Samsun bombardımanının beklenen ve arzu edilen Anadolu barışını felce uğrattığı yönündedir. Bu konuda Tercüman-ı Hakikat gazetesi: "Samsun bombardımanı, bu kadar temenni edilen barış için pek uğursuz bir harekettir" biçiminde değerlendirme yapmıştır. Gazetenin Paris'ten edindiği bilgiye göre, Osmanlı hükümeti, Yunan filosunun Samsun limanını bombardıman etmesini protesto etmekle kalmamış, hasara neden olan bombardımanın Anadolu'da beklenen barışı gölgelediğini de öne sürmüştür. ${ }^{82}$

Samsun bombardımanı olayının sıcaklığında, İngiliz Avam Kamarası'nda Anadolu barışı meselesi de ele alınmıştır. Anadolu barışı noktasında Mr. Harmsworth görüşlerini parlamentoda açıklarken, İngiliz hükümetinin barıştan yana bulunduğunu ancak Ankara hükümetinin yapılan bütün önerileri reddettiğinden yakınmıştır. ${ }^{83}$ Bunun üzerine İngiliz Avam Kamarası'nda söz alan Binbaşı Glyn, Dışişleri Bakanlığı Müsteşarı'na, İngiliz hükümetinin Müttefiklerle birlikte veya tek başına onurlu bir barış yapıp yapmayacağını, böyle bir antlaşmaya varmak için Yunanistan ve Türk milliyetçileri arasında başka adımlar atıp atmadığını, Yunanistan'ın Müttefiklerin sunduğu ateşkes koşullarını kabul ettiğinden beri, erken bir çözüm bekleyip beklemediğini ve mevcut Yunanistan anayasasını tam olarak kabul edip etmeyeceğini sormuştur. Harmsworth'de sorunun ilk kısmıyla ilgili cevap verdiğini, diğer taraftan İngiliz hükümetinin her zaman Yunan anayasası ilkelerini kabul ettiğini söylemiştir. ${ }^{84}$

Harmsworth, Ankara hükümetinin kendisine yapılan önerileri reddettiğini söylese de aslında İngiliz hükümeti sadece Ankara'daki TBMM hükümetiyle temas halinde değildi. Bu noktada İngiliz hükümeti, Anadolu barışı çalışmalarını yürütürken, İstanbul hükümeti ile Ankara hükümetini birbirine düşürmek gibi bir strateji takip edecektir. Harmsworth,

80 Hâkimiyet-i Milliye, 15 Haziran 1922, No: 532, s. 1.

81 Tercüman-ı Hakikat, 11 Haziran 1922, No: 14792, s. 1.

82 Tercüman-ı Hakikat, 17 Haziran 1922, No: 14797, s. 1.

83 GREECE AND TURKEY, HC Deb 12 June 1922 vol 155 cc20-1; Bu kapsamda Tercüman-ı Hakikat gazetesindeki haber şöyledir: "ingiltere hükümeti 25 Mayıs'tan beri Anadolu barışının muhafazası için bütün kuvveti ile çalıştı. Bu konuda hiçbir gayretten geri durmadı. Hâlbuki Ankara hükümetinin Paris Konferansı sırasında, mütareke ile Anadolu meselesinin görüşülerek neticelendirilmesi için sarf olunan teklifleri kabul etmekten çekinmesi, Ingiliz hükümetin mesaisini güçleştirmektedir ve bu zorluk giderek de artmaktadır.", Tercüman-ı Hakikat, 20 Haziran 1922, No:14800, s. 1. Anlaşılacağı üzere Ankara hükümeti, barışı güçleştiren taraf konumuna taşınmıştır.

84 GREECE AND TURKEY, HC Deb 12 June 1922 vol 155 cc47-8W. 
Mustafa Kemal ile yapılan görüşmeye, İngiliz hükümetinin nasıl baktığını açıklarken: "Taraflardan sadece biriyle değil de Ankara, Istanbul ve Yunan hükümetleri olmak üzere üçüyle birden görüşmeyi doğru buluyoruz" ${ }^{\prime 85}$ demiştir.

Taraflardan üçü ile görüşmeyi doğru bulan İngiltere'ye göre Samsun bombardımanı Anadolu barışı ihtimallerini azaltan bir gelişmedir. Genel olarak İngiltere'nin fikri bu merkezdedir. Avam Kamarası'nda Dışişleri Bakanı Müsteşarı, bir mebusun sorusuna cevap verdiği sırada katı bir bakış açısıyla Samsun bombardımanının haklı gösterebileceğini bununla beraber İngiltere hükümetinin barış ihtimalini azaltabilecek hadiseden dolayı derin bir şekilde etkilendiğini ifade etmiştir ${ }^{86}$ Ancak aynı İngiltere, Samsun bombardımanı olayını kullanarak, Anadolu'ya bir soruşturma heyeti gönderme planları içerisindedir. İngiliz Başbakanı Loyd George, mütareke vasıtasıyla yapamadığı Anadolu'ya heyet gönderme planını, azınlıkların durumunu tetkik bahanesiyle gerçekleştirmek istemiştir. Böylece tetkik komisyonu adı altında Anadolu'da Hristiyanların durumunu incelemek isteyen Ingiltere, bu bahaneyle, hem kendi komutanlarını hem de Müttefik Devletlerin subaylarını Anadolu'ya sokarak, Türklerin askeri gücü hakkında bilgi sahibi bulunmayı istemiştir. ${ }^{87} \mathrm{Bu}$ bağlamda Türk basını, Anadolu'da Hristiyanlar ve Müslümanlar arasına nifak sokmaya çalışan İngilizlerin tahkikat talebi ile aslında bütün dünyayı ayaklandıracağını zannettiği yorumunda bulunmuştur. Oysaki Türk basınına göre, tahkikat talebi olsa olsa Yunanlılar tarafından işlenen vahşetleri bütün cihana ilan edecektir. Görüşlerini Fransız matbuatına dayandıran Anadolu basını, tahkikat yapıldığı takdirde Türk cephesinin gerisinde meydana gelecek hadiselerde mesuliyetin ihtilali tertip edenlere ait olacağını da öne çıkarmıştır. ${ }^{88}$

Anadolu barışı noktasında Tercüman-ı Hakikat gazetesinin değerlendirmesi Ankara'dan İstanbul'a gelen bir gazetecinin beyanatına dayandırılmıştır: "Samsun bombardımanından önce barış için kamuoyunda bir eğilim mevcuttu. Ancak Yunanlıların bu son taarruzları her çeşit barış ihtimalini yok etmiştir." 89 Türk basınına göre barış artık bir hayalden ibarettir, çünkü Samsun bombardımanı barış çabalarını bütünüyle baltalamıştır. Diğer taraftan, Türk tarafının Paris Konferansı kararlarını görüşmek üzere İzmit'te bir konferans toplanması teklifine Fransa ile İtalya olumlu yaklaşsa da İngiltere buna açıkça karşı çıkmıştır. ${ }^{90}$ Bunun nedeni İngilizlerin Türk-Yunan barışının ancak Müttefiklerin Paris Konferansı'nda belirlediği şartlar üzerine gerçekleşmesini istemesidir.

Anadolu barışının ne zaman olacağını sorgulayan parlamentoda, Mr. Herbert, Mustafa Kemal'in yuvarlak masa toplantısına çağrılıp çağrılmayacağını ve Yunan Kralı́nın tanınıp tanınmayacağını sorması üzerine İngiliz başbakanı, İngiltere'nin Yunan politikasında bir değişikliğin bulunmadığını söylemiştir. Bu cevap üzerine Mr. Herbert'in, Yakın Doğu politikalarının Yunanlıların İzmir çıkarmasından sonra başarısızlığa uğradığını, dolayısıyla İngiliz hükümetinin bu politikayı değiştirmeyi düşünüp düşünmediğini sorması üzerine, başbakan, Mr. Herbert'in açıklamasına katılmadığını aktararak, zamanla dünyanın bu bölgesinde takip edilen İngiliz politikasının haklı çıkacağından emin bulunduğunu konuşmasına ilave etmiştir. Ardından Türkiye ile barış görüşmelerinin devam etmesi üzerine daha fazla açıklama yapamayacağından dolayı, 21 Haziran tarihli parlamento oturumuna bakması gerektiğini belirtmiştir. ${ }^{91}$

85 NEAR EAST, HC Deb 22 June 1922 vol 155 c1496.

86 Tercüman-ı Hakikat, 26 Haziran 1922, No: 14806, s. 1.

87 Abdülahad Nuri, "Tarihten Korkmayanlar", Açıksöz, 21 Haziran 1922, No: 513, s. 1.

88 Hâkimiyet-i Milliye, 14 Haziran 1922, No: 531, s. 1.

89 Tercüman-ı Hakikat, 28 Haziran 1922, No: 14808, s. 1.

90 Hâkimiyet-i Milliye, 26 Haziran 1922, No: 541, s. 1.

91 NEAR EAST, HC Deb 06 July 1922 vol 156 cc561-2. 
18 Temmuz 1922 parlamento oturumunda Kenworthy, başbakandan, Küçük Asya'da barışı sağlamak adına yapılan müzakerelerde herhangi bir ilerleme kaydedip kaydetmediğini, Müttefik temsilcilerin hazır bulunmasıyla Türk ve Yunanlılar arasında prensipte bir toplantı yapılıp yapılmadığını, toplantının nerede ve ne zaman yapılacağını ve müzakereler devam ederken Yunan savaş gemilerinin, Türkiye'nin deniz yolu trafiğine müdahale etmesine izin verilip verilmeyeceğini öğrenmek istemiştir. Dışişleri Bakanlığı Müsteşarı Harmsworth de Müttefik hükümetlerin temsilcileri ile Atina hükümetleri arasında bir toplanma sorunu olduğunu, İstanbul ve Ankara hükümetleri ile hâlâ görüşüldüğünü ve ilerlemenin umulduğunu parlamentoya bildirmiştir. Kenworthy'nin sorusunun son kısmına ise İngiliz hükümetinin savaşanların hakları doğrultusunda yeniden değerlendirme yapmayacağını, bu durumun uluslararası hukuk ile zaten 1911'de kabul edildiğini belirterek, Yunan hükümetinin ancak, sadece mutlak savaş kaçakçılığını durdurma niyetini parlamentoya iletmiştir. ${ }^{92}$

Anlaşılacağı üzere Samsun bombardımanından sonra Anadolu barışı bağlamında 1922 Haziran'ı belirsizlikle geçmiştir. Ancak yine de sık sık barış söylemlerinin İngiliz parlamentosunda dile getirilirken, bir toplanma sıkıntısından bahsedilmesi, İngilizlerin TBMM hükümetinin İzmit teklifine olumlu yaklaşmadığını, ancak diğer taraftan Türkiye'ye teklif edilen barış şartlarını iyileştirmek isteyen İngilizlerin yeni bir konferanstan bahsetmesi muhtemelen İngiltere'nin yeniden başlayacağını öngördüğü bir Türk taarruzuna karşı aldığı tedbirlerdir. İngiltere'nin barışı geciktiren tedbirleri karşısında Türk milletinin Sevr'in başlıca maddelerinin değiştirilmesi neticesinde ortaya çıkan Paris Konferansı şartlarını kabul etmesi mümkün değildi. Misâk-ı Millî́de ısrarcı bulunan Türk milleti ve kamuoyu taarruz hazırlıklarına hız verecek ve "Büyük Taarruz"u başlatacaktır. İngiltere'ye verilen bu cevap Mustafa Kemal Paşa'nın milletine ve ordusuna olan inancının ne kadar kuvvetli bulunduğunu ve vatanını kurtarabilecek durumda olduğunu göstermiştir.

Aynı durum Yunan kamuoyunda da söz konusudur. Bu bağlamda, Yunan basınında, Samsun bombardımanından önce çıkan yazılarda sulhtan bahsedildiği, hatta Türk tarafının resmen tekzip etmesine rağmen, bazı gazetelerin Türkler-Yunanlılar arasında doğrudan doğruya ve bilvasıta görüşmelerin söz konusu olduğunu kamuoyuna aktardığı anlaşılmaktadır. Bu tarz barış söylentileri, her ne kadar tekzip edilse de Türk basınında, Yunanlıların akıllarını başlarına topladıkları şeklinde değerlendirilmiştir. Zaten Türk basınına göre, Yunanlılar Anadolu'ya taarruz etmeseydi, Yunan-Türk muharebesi ortaya çıkmayacak dolayısıyla bir mukabele ve müdafaaya gerek kalmayacaktı. Böylece Anadolu'da yaşanılanlar karşısında Yunan basınında çıkan sulh yazıları, yine de Türk basınında, Yunanlıların nihayet uykudan ayılmış oldukları yönünde birtakım fikirlerin işlenmesine yol açmıştır. Ancak Samsun bombardımanından sonra Yunan basını ağız değiştirecek ve Yunan ordusunun meseleyi tek başına çözeceğinden bahsetmeye başlayacaktır. ${ }^{93}$ Bu durum Yunanlıların yeniden silaha sarılacağının bir ifadesidir.

\section{Sonuç}

Sakarya Savaşı'ndan Büyük Taarruz Savaşı'na kadar geçen yaklaşık bir yıllık süre zarfında hem Türkler, hem de Yunanlılar ve İtilaf Devletleri, Anadolu'da barış beklentilerini sürdürmüştür. Özellikle de Sakarya Savaşı sonrasında Yunan ordusunun geri çekilmesi bir taraftan Yunanistan'da hayal kırıklığına neden olsa da diğer taraftan Yunan ve Batı kamuoyunda, Anadolu'da barış yapılması söylemlerini "Şark Salâhı" adı

92 GREECE AND TURKEY, HC Deb 18 July 1922 vol 156 cc1910-1.

93 "Yunan Teraneleri", Hâkimiyet-i Milliye, 14 Haziran 1922, No: 531, s. 1. 
altında güçlendirmiştir. Bununla birlikte ittilaf Devletlerinin vasıtasıyla Şark Salâhı'nın çözümü noktasında müzakereler yapılsa da müzakerelerden neticeyi sağlayacak bir sonuç çıkmamıştır. Barış noktasında kendisini Türk halkının tek meşru temsilcisi nitelendiren TBMM hükümeti, barış şartları net olarak belirlenmeden ve Anadolu'nun tahliyesi gerçekleşmeden, Misâk-ı Millî şartlarını taşımayan bir barışa razı bulunmadığını öne çıkarmıştır. Bu bağlamda Mustafa Kemal Paşa'nın İzmit'te bir barış konferansı toplanması teklifini İngiltere sürüncemede bırakmıştır. Üstelik barış söylemleri ve söylentileri etrafında Ingiltere'nin desteklediği Yunan filosu siyasi ve askeri gayelerle Samsun'u bombardıman ederek, Türkleri Hristiyan Rumlara ve Samsun'daki Amerikan vatandaşlarına karşı tahrik ettirmek amacını gütmüştür.

Bu bağlamda bu amaç, daha önceki yıllarda Balkanlarda uygulanan ve ayrılıkçı sonuçlar doğuran politikaların Anadolu'da da uygulamaya konulduğunun bir kanıtıdır. Bu açıdan azınlık nüfusu barındıran yerlerin, Batı için uyguladığı saldırgan politikaların, emperyalist gayelerin perdelenmesinin ve kendi iç kamuoylarında destek elde edebilmelerinin bir aparatı olarak görüldüğünden bahsedilebilir. Nitekim Samsun bombardımanı esnasında da Yunanlılar, Avrupa'da, Türklerin Hristiyanlara zülüm yaptıklarına dair kopartılan gürültüleri teyit ettirmek ve kendilerini de sözde bu zulmün sonlandırıcısı olarak betimletmek istemişlerdir. Aynı zamanda da Sakarya Savaşı yenilgisi nedeniyle hayal kırıklığına uğrayan Rumları cesaretlendirmek ve yüreklendirmek emelini gerçekleştirmek isteyen Yunanistan, TBMM hükümetinin aldığı tedbirlerle beraber İslam ve Hristiyan vatandaşların kendi meşguliyetleriyle ilgilenmeleri sayesinde, elde etmek istediği siyasi gayeleri gerçekleştirmemiştir.

Diğer taraftan askeri boyut kapsamında bombardımanın bir amacı da Büyük Taarruz'dan önce Samsun limanında bulunan cephanenin sevkiyatını önlemek olarak sunulmuştur. Ancak neticede, Samsun'da meydana gelen maddi zarar ve can kaybına karşılık, buradaki limandan içerilere sevk edilen silah ve mühimmata pek zarar gelmemiştir. Samsun halkının Hristiyanlara karşı saldırgan vaziyet almayarak bu konuda gösterdiği fedakârlıkta, İngiltere'nin Hristiyanlara zulmediliyor gürültülerinin önüne geçmiştir. Bu yaşananlarda hatırda tutulması gereken bir hususta; özelinde Yunanistan'ın genelinde Batı'nın kazanmak için uluslararası hukuku rahatlıkla terk ederek "açık şehirler" üzerinde dahi operasyon yapmaları ve sivil kayıpları umursamamalarıdır.

Samsun bombardımanı olayı TBMM oturumlarında ve basında protesto edilecek ve Yunanistan'ın arkasındaki güç İngiltere de basın kanalıyla eleştirilecektir. Aynı meselede Ingiltere'nin pozisyonu yine bizzat İngiliz Avam Kamarası oturumlarında eleştiriye varacak biçimde gündeme gelmiştir. Gerek Türk basınında ve gerekse İngiliz Avam Kamarası oturumlarında Samsun bombardımanı Anadolu barışını olumsuz etkileyen bir vaka biçiminde ele alınmıştır. Özellikle Avam Kamarası'ndaki tartışmalarda, tarafsız bölge konumundaki Boğazlardan Yunan gemilerinin bölgeyi nasıl geçtikleri ve bombardımanda kullandıkları mühimmatların menşei ile ilgili üyelerin sorularına dönemin İngiliz yetkililerin kaçamak cevap verdikleri görülmektedir.

Kısaca Samsun bombardımanı, Milli Mücadele'nin elde ettiği başarılarla “Anadolu Sulhu" söylemlerinin işlerlik kazanmaya başladığı bir süreçte, İngiltere'nin himayesinde Yunanlılarca gerçekleştirilmiştir. Bombardıman, savaşın sürdürülmesinde argümanlar üretecek bir propaganda sahası olarak planlanmıştır. Söz konusu propaganda sahasında, bölgedeki Hristiyanlar, sözde zulüm gören kişiler olarak kurgulanmıştır. Kurulan bu kurgu üzerinden, uluslararası hukuka aykırı olarak açık bir şehirde yapılan bombardıman gerekli ve masum gösterilmeye çalışılmıştır. 


\title{
Kaynakça
}

\author{
A. Arşiv Belgeleri \\ Türkiye Cumhuriyeti Cumhurbaşkanlığı Devlet Arşivleri Başkanlığı Cumhuriyet Arşivi \\ (BCA); \\ BCA, Fon No: 30-18-1-1, Yer No: 5-17-20. \\ BCA, Fon No: 30-18-1-1, Yer No: 5-18-15. \\ B. Resmi Yayınlar
}

\section{Türkiye Büyük Millet Meclisi Zabıt Ceridesi;}

TBMM Zabıt Ceridesi, 1. Dönem, 20. Cilt, 50. Birleşim, 08.06.1922.

TBMM Zabıt Ceridesi, 1. Dönem, 20. Cilt, 51. Birleşim, 10.06.1922.

\section{Records of the House of Commons (Avam Kamarası Zabıtları); \\ BOSPHORUS (NAVAL CONTROL), HC Deb 21 June 1922 vol 155 c1279. \\ GREECE AND TURKEY, HC Deb 26 June 1922 vol 155 cc1650-1. \\ GREECE AND TURKEY, HC Deb 10 July 1922 vol 156 cc865-6W. \\ GREECE AND TURKEY, HC Deb 12 June 1922 vol 155 cc20-1. \\ GREECE AND TURKEY, HC Deb 12 June 1922 vol 155 cc47-8W. \\ GREECE AND TURKEY, HC Deb 18 July 1922 vol 156 cc1910-1. \\ GREECE AND TURKEY, HC Deb 28 June 1922 vol 155 cc2036-7. \\ GREECE AND TURKEY, HC Deb 19 June 1922 vol 155 cc816-7. \\ NEAR EAST, HC Deb 06 July 1922 vol 156 cc561-2. \\ NEAR EAST, HC Deb 22 June 1922 vol 155 c1496. \\ NEAR EAST, HC Deb 30 May 1922 vol 154 cc2027-54.}

SAMSUN (BOMBARDMENT), HC Deb 12 July 1922 vol 156 cc1198-9.

SAMSUN (BOMBARDMENT), HC Deb 14 June 1922 vol 155 cc337-8.

SAMSUN (BOMBARDMENT), HC Deb 21 June 1922 vol 155 cc1279-80.

SAMSUN (BOMBARDMENT), HC Deb 29 June 1922 vol 155 c2331W.

TURKEY AND GREECE, HC Deb 20 June 1922 vol 155 cc1036-7.

C. Süreli Yayınlar (Gazeteler);

Hâkimiyet-i Milliye, Tercüman-ı Hakikat, The Times, Yeni Gün.

D. Kitap ve Makaleler;

Akandere, Osman-Güven Cemal (2002) , “Ingiliz Generali Townshend'in Anadolu Seyahati ve Mustafa Kemal Paşa ile Konya'da Yaptığı Görüşme”, sÜ Atatürk IIlkeleri ve Inkılap Tarihi Araştırma ve Uygulama Merkezi Ata Dergisi, S. 9, ss. 1-38.

Atatürk, Mustafa Kemal (1997), Nutuk, Ankara, Atatürk Araştırma Merkezi Yayınları.

Biber, Tuğba Eray (2016), Karadeniz Rumları ve Yunanistan (1914-1923), İstanbul, Yeditepe Yayınevi.

Bozkurt, Abdurrahman (2010), "Itilaf Devletleri'nin Türk-Yunan Savaşı'nda Tarafsızlık ilanı (13 Mayıs 1921)", Atatürk Araştırma Merkezi Dergisi, C. XXVI, S. 76, ss. 27-54.

Doğanay, Rahmi (2006), "İstiklal Harbinde Samsun'daki Amerikan Filosu”, Geçmişten Geleceğe Samsun, ss. 163-174. 
Doğanay, Rahmi (2016), Milli Mücadele'de Karadeniz (1919-1922), Ankara, Atatürk Araştırma Merkezi Yayınları.

Gönlübol, Mehmet, Sar, Cem (2013), Atatürk ve Türkiye’nin Dış Politikası, Ankara, Atatürk Araştırma Merkezi Yayınları.

Leber, George J. (1971), The 1821 Greek War Of Independence and America's Contributions To The Greek Cause, Order of Ahepa, Washington.

Nutku, Emrullah (1962), "Samsun Bombardımanı ve Kahramanlık Yarışı", Yakın Tarihimiz, C. 4 , S. 41 , ss. $60-61$.

Okur, Mehmet (2006), Milli Mücadele'de Karadeniz Bölgesi'ne Yönelik Ingiliz Faaliyetleri, Ankara, Genelkurmay Askeri Tarih ve Stratejik Etüt Başkanlığı Yayınları.

Oran, Baskın (2014), “1919-1923: Kurtuluş Yılları: Dönemin Bilançosu ve Dönemin Yönetimi", Türk Dış Politikası, C. I (1919-1980), Editör: Baskın Oran, İstanbul, Iletişim Yayınları, ss. 110-113.

Özüçetin, Yaşar (2004), "Millî Mücadele İçerisinde "19 Mayıs 1919” Gazi Üniversitesi Kırşehir Eğitim Fakültesi, Cilt 5, Sayı 2, ss. 65-74.

Uzgel, İlhan, Ömer Kürkçüoğlu (2014), “Batı Avrupa'yla İlişkiler: İngiltere'yle İlişkiler”, Türk Dış Politikası, C. I (1919-1980), Editör: Baskın Oran, İstanbul, Illetişim Yayınları, ss. 139-147.

\section{E. Süreli Yayın Makaleleri;}

Abdülahad Nuri, "Samsun'un Bombardımanı”, Açıksöz, 10 Haziran 1922, No: 503.

Abdülahad Nuri, "Tarihten Korkmayanlar", Açıksöz, 21 Haziran 1922, No: 513.

Ahmet Emin, "Samsun'un Bombardımanı", Vakit, 9 Haziran 1922, No: 1614.

Ali Kemal, "Ne Vahşiyane Bir Hareket", Peyam-ı Sabah, 11 Haziran 1922.

Hüsnü, "Ingilizlerin Son Oyunu”, Açıksöz, 24 Mayıs 1922, No: 493

“Mesul Kimdir?”, Hâkimiyet-i Milliye, 9 Haziran 1922, No: 527.

“Samsun'un Bombardımanı", Açıksöz, 8 Haziran 1922, No: 502.

"Yeni Bir Tahrik-Karlık", İkdam, 10 Haziran 1922, No: 9063.

"Yunan Teraneleri", Hâkimiyet-i Milliye, 14 Haziran 1922, No: 531.

F. Internet Kaynakları;

https://en.wikipedia.org/wiki/Constantine_Kanaris, (IGT: 04.09.2019) 